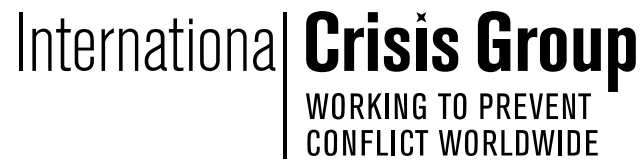

\section{Women, Violence and Conflict in Pakistan}

Asia Report №265 | 8 April 2015 


\section{Table of Contents}

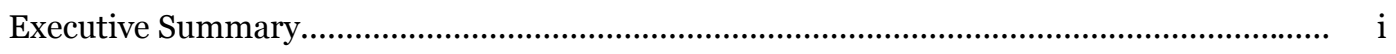

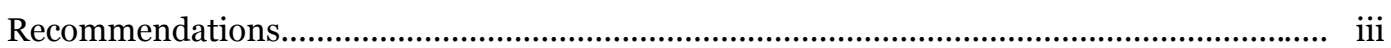

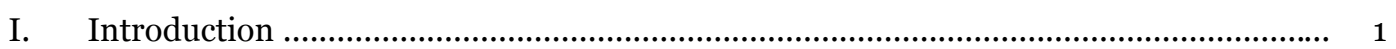

II. Institutionalised Violence against Women ......................................................... 2

A. Discriminatory Legislation ........................................................................ 2

B. The State's Failure to Protect......................................................................... 5

III. Women and the Democratic Transition .............................................................. 8

A. Legislative Gains: Two Steps Forward, One Back ............................................ 8

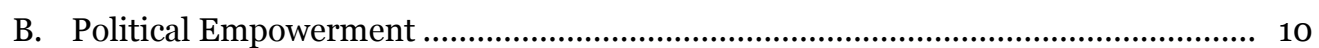

IV. Political Empowerment and Justice for Women in Conflict Zones............................. 13

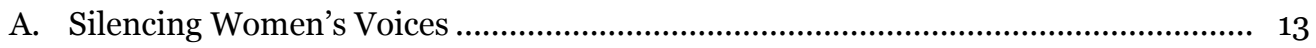

1. Political participation in FATA …........................................................... 13

2. Political participation in KPK................................................................. 14

B. Access to Justice in FATA and KPK............................................................. 16

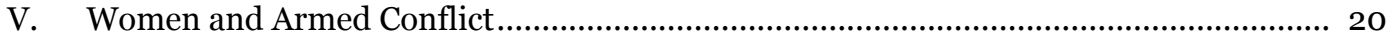

A. Life in Conflict Zones .................................................................................... 20

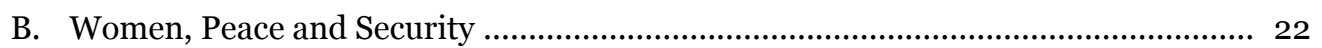

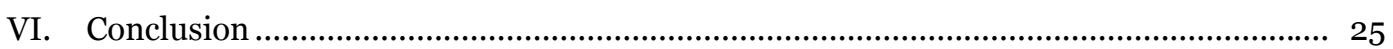

\section{APPENDICES}

A. Map of Pakistan ........................................................................................... 26

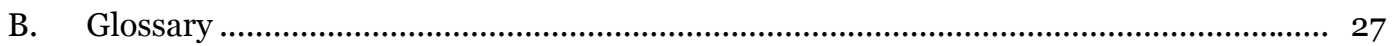

C. About the International Crisis Group .................................................................. 28

D. Crisis Group Reports and Briefings on Asia since 2012 ........................................ 29

E. Crisis Group Board of Trustees ............................................................................ 31 


\section{Executive Summary}

Eight years into its democratic transition, violence against women is still endemic in Pakistan, amid a climate of impunity and state inaction. Discriminatory legislation and a dysfunctional criminal justice system have put women at grave risk. Targeted by violent extremists with an overt agenda of gender repression, women's security is especially threatened in the conflict zones in Khyber Pakhtunkhwa (KPK) province and the Federally Administered Tribal Areas (FATA). On 8 March, International Women's Day, Prime Minister Nawaz Sharif vowed that his government would take all necessary legislative and administrative steps to protect and empower women. If this pledge was in earnest, his Pakistan Muslim League-Nawaz (PML-N) government should end institutionalised violence and discrimination against women, including by repealing unjust laws, countering extremist threats, particularly in KPK and FATA, and involving women and their specially relevant perspectives in design of state policies directly affecting their security, including strategies to deal with violent extremist groups.

Women in the past were the principal victims of state policies to appease violent extremists. After democracy's return, there has been some progress, particularly through progressive legislation, much of it authored by committed women's rights activists in the federal and provincial legislatures, facilitated by their increased numbers in parliament. Yet, the best of laws will provide little protection so long as social attitudes toward women remain biased, police officers are not held accountable for failing to investigate gender-based crimes, the superior judiciary does not hold the subordinate judiciary accountable for failing to give justice to women survivors of violence, and discriminatory laws remain on the books.

Laws, many remnants of General Zia-ul-Haq's Islamisation in the 1970s and 1980s, continue to deny women their constitutional right to gender equality and fuel religious intolerance and violence against them. Their access to justice and security will remain elusive so long as legal and administrative barriers to political and economic empowerment remain, particularly the Hudood Ordinances (1979), FATA's Frontier Crimes Regulations (FCR) (1901) and the Nizam-e-Adl (2009) in KPK's Provincially Administered Tribal Areas (PATA).

The government has a constitutional obligation and international commitments, including under the UN Convention on the Elimination of All Forms of Discrimination Against Women (CEDAW), to combat gender inequality and remove such barriers to women's empowerment. Repealing discriminatory legislation and enforcing laws that protect women, including by ensuring that they have access to a gender-responsive police and courts, are essential to ending the impunity that promotes violence against women.

The extent to which rights violations go unpunished is particularly alarming in FATA and KPK, where women are subjected to state-sanctioned discrimination, militant violence, religious extremism and sexual violence. Militants target women's rights activists, political leaders and development workers without consequences. The prevalence of informal justice mechanisms in many parts of Pakistan, particularly in Pakhtunkhwa and FATA, are also highly discriminatory toward women; and the 
government's indiscriminate military operations, which have displaced millions, have further aggravated the challenges they face in the conflict zones.

In KPK and FATA, and indeed countrywide, women's enhanced meaningful presence in decision-making, including political participation as voters and in public office, will be central to sustainable reform. Pakistan should invest in their empowerment and reflect their priorities in all government policies, including counter-insurgency and peacebuilding efforts. All too often, women comprise a majority of both the intended victims of the insurgency and the unintended victims of the counter-insurgency response.

National and provincial legislation to enhance protections for women is a step in the right direction, but much more is needed to safeguard them against violence and injustice and ultimately to consolidate Pakistan's democratic transition. 


\section{Recommendations}

To curb violence against women and promote gender equity

\section{To the executives and legislatures of Pakistan's federal and provincial governments:}

1. Respecting international commitments and constitutionally guaranteed fundamental rights, the National Assembly should amend all laws that discriminate against women in the Penal Code and Evidence Act and repeal the Hudood Ordinances in their entirety; all provincial legislatures should pass and implement laws to protect and empower women, including by criminalising and taking effective measures to prevent domestic violence.

2. The National Assembly should approve the Anti-Rape Laws (Criminal Laws Amendment) Act, the Anti-Honour Killings Laws (Criminal Laws Amendment) Act and the Torture, Custodial Death and Custodial Rape (Prevention and Punishment) Act, passed by the Senate in March 2015.

3. The national legislature should establish a quota of general (directly-elected) National Assembly seats, in addition to the existing reserved (unelected) seats, for women legislators, and the parliament's rules of procedures should be amended to ensure a certain number of parliamentary committees are headed by women.

4. The federal and provincial governments should prioritise the development of a gender-responsive security apparatus, including by increasing the numbers of policewomen, particularly in senior positions; building police capacity to investigate crimes against women; and strengthening the National Police Bureau (NPB) and its gender crimes cell's liaison with provincial authorities.

5. The provincial governments should build the capacity of the Provincial Commissions on the Status of Women (PCSW) to monitor violations of women's rights and to ensure that government policies and legislation produce gender equality and women's empowerment.

\section{To the international community, particularly the UN and donor countries:}

6. Continue and enhance support for developing gender-responsive policing and women's rights bodies; also ensure that women's needs, rights and priorities are meaningfully addressed in all aid programing.

To protect and empower women in conflict-affected areas

\section{To the federal government and the Khyber Pakhtunkhwa (KPK) provincial government:}

7. Repeal the Frontier Crimes Regulations (FCR) in FATA and the Nizam-e-Adl in PATA and extend the jurisdiction of superior courts to FATA so that citizens there can seek protection of the fundamental rights the constitution guarantees them. 
8. Include women and protect their rights and interests in counter-insurgency and peacebuilding strategies.

9. Promote civilian-led and civilian-devised humanitarian assistance and take measures to ensure that displaced women receive timely and adequate assistance, including by facilitating national and international NGOs' access to areas of displacement and investigating allegations of discriminatory assistance.

10. The federal and KPK governments should ensure that women can exercise their rights of franchise and to stand for public office; and the Election Commission of Pakistan (ECP) should investigate all cases of women having been barred from voting or contesting elections.

\section{To the international community, particularly the UN and} donor countries:

11. Ensure that women's needs are adequately assessed in relief and rehabilitation assistance to conflict-affected and internally displaced persons.

12. Encourage the federal government to repeal the FCR and Nizam-e-Adl and to support women's rights in the conflict zones and participation in the development of counter-insurgency/counter-terrorism policies and peacebuilding efforts.

Islamabad/Brussels, 8 April 2015 


\section{Women, Violence and Conflict in Pakistan}

\section{Introduction}

Women's security and their political, social and economic status in Pakistan are undermined by hardened social biases, discriminatory legislation and unresponsive state institutions; their lives and livelihoods are also threatened by violent extremism. ${ }^{1}$ On 10 December 2014, Malala Yousafzai received the Nobel Peace Prize in Oslo for her promotion of girls' education. The young activist had made global headlines after surviving an attack in 2012 by Mullah Fazlullah's Tehreek-e-Taliban Pakistan (TTP-Taliban Movement of Pakistan) in the Swat district of Khyber Pakhtunkhwa (KPK) province three years after the military claimed to have countered militant threats there. Belying similar claims of success in ongoing military operations in the North Waziristan and Khyber agencies of the Federally Administered Tribal Areas (FATA), women and girls are still targeted by violent extremists.

There is urgent need to counter gender inequity and violence against women in the Pashtun heartland but also throughout a country that ranks second to last in the World Economic Forum's 2014 measurement of gender-based disparities in politics, economy, health, and education. ${ }^{2}$

This report presents an overview of both legal frameworks that have institutionalised discrimination and fuelled religious intolerance and violence against women and a dysfunctional criminal justice system that has failed to protect them and emboldened extremists. It assesses progress achieved and opportunities lost since democracy was restored. With a special focus on FATA and KPK, where the state's writ and the rule of law is fast shrinking, it discusses the potential role for women in devising state policies to counter violent extremism and in the prevention and resolution of conflict. It is based on interviews with government officials, including police, women's rights activists, lawyers, NGO workers, and UN and donor representatives

\footnotetext{
${ }^{1}$ Crisis Group Asia Reports $\mathrm{N}^{\circ}$ 242, Pakistan: Countering Militancy in PATA, 15 January 2013; $\mathrm{N}^{\circ} 196$, Reforming Pakistan's Criminal Justice System, 6 December 2010; № 178, Pakistan: Countering Militancy in FATA, 21 October 2009; $\mathrm{N}^{\circ} 164$, Pakistan: The Militant Jihadi Challenge, 13 March 2009; and $\mathrm{N}^{\circ} 160$, Reforming the Judiciary in Pakistan, 16 October 2008.

${ }^{2}$ Pakistan was 141st of the 142 countries considered; of the other South Asian countries, India came in at 114, Nepal at 112 and Sri Lanka at 79. "Global gender gap index 2014: Rankings", World Economic Forum, www.weforum.org.
} 


\section{Institutionalised Violence against Women}

\section{A. Discriminatory Legislation}

Despite the 1973 constitution's guarantee of equality for citizens regardless of gender, ${ }^{3}$ legislative progress to redress the inequalities suffered by women has been uneven at best. Islamists have repeatedly opposed the few relevant laws, and successive governments have been lax in implementing them. Until the mid-200os, the 1961 Muslim Family Laws Ordinance (MFLO, still in place) was the only substantial legislation that granted women some benefits and rights in family laws. Offering a degree of protection for matrimonial rights, it made marriage registration compulsory and required local authorisation for divorce and the permission of the Arbitration Council for polygamous marriage. ${ }^{4}$ The 1929 Child Marriage Restraint Act, also still in place, sets the bar at eighteen for men and sixteen for women, except in Sindh province, whose Child Marriages Restraint Act (2014) raised the minimum age to eighteen for both. ${ }^{5}$ However, these laws will only be effective if social attitudes toward the girl child change.

General Zia-ul-Haq's regime (1977-1988) institutionalised state-sanctioned gender discrimination, undermining the few existing legal protections and relegating women to second-class citizens. Relying on Islamisation to legitimise military rule, Zia used presidential ordinances to replace part of the Pakistan Penal Code with Islamic jurisprudence and punishments. ${ }^{6}$ The Hudood Ordinances criminalised all consensual sexual intercourse between adults outside marriage; female minors could also be charged with zina (extramarital sexual intercourse) if the age of puberty was reached. Till then, only adultery had been illegal, although a female accused of adultery was not punished under the law. ${ }^{7}$

Punishments under the Hudood Ordinances were divided between Hadd (Quranic) and Tazir (non-Quranic). If there was insufficient proof for Hadd - four adult Muslim witnesses, "truthful persons [who] abstain from major sins" - the accused was still liable to Tazir. In rape (zina bil jabr) and zina cases, the Hadd punishment was stoning to death if the offender was married and mandatory public flogging if unmarried. $^{8}$

\footnotetext{
3 "All citizens are equal before law and are entitled to equal protection of law ... there shall be no discrimination on the basis of sex ... nothing in this Article shall prevent the State from making any special provision for the protection of women and children" (Article 25); and "steps shall be taken to ensure full participation of women in all spheres of national life" (Article 34).

${ }^{4}$ Under Islamic law, a man can contract four marriages provided the wife or wives approve.

${ }^{5}$ Muslim Family Law Ordinance, 1961; "Sindh assembly passes bill declaring marriage under 18 punishable by law”, The Express Tribune, 28 April 2014. On 6 March 2015, the Punjab assembly amended the 1929 Child Marriage Act, providing stricter punishments for those involved in arranging such unions but retained sixteen as the legal age for girls. "Punjab approves stricter Child Marriage Restraint Act”, The News, 6 March 2015.

${ }^{6}$ Promulgated on 9 February 1979, the ordinances were Offences Against Property (enforcement of Hudood) Ordinance; Prohibition (enforcement of Hadd) Order; Offence of Qazf (enforcement of Hadd) Ordinance"; Offence of Zina (enforcement of Hudood) Ordinance; and Execution of Punishment by Whipping Ordinance. Hudood is the plural of Hadd, a limit or prohibition, and refers to offences for which a punishment is specified under Islamic law.

${ }^{7}$ Asma Jahangir and Hina Jilani, The Hudood Ordinances: A Divine Sanction? (Lahore, 2003), pp.85-86. Asma Jahangir is a member of the Crisis Group Board of Trustees.

8 "Offence of Zina (enforcement of Hudood) Ordinance, 1979", Section 8.
} 
The evidentiary requirements under the Hadood Ordinances for the imposition of Hadd (the most extreme punishment) do not accept the testimony of women. Although Hadd punishment has never been executed, the law severely undermines the value of a female's testimony. The 1984 Qanoon-e-Shahadat (the law of evidence) also discriminates against women. ${ }^{9}$ Until the law was amended (discussed below), to file a complaint of rape was risky; confessed extramarital sexual intercourse by the victim could be determined to have taken place with her consent and the complaint converted to an accusation of zina under which the victim of rape was herself prosecuted.

The zina ordinance lent itself to massive abuse, with thousands imprisoned for marrying against family will, seeking divorce, escaping domestic abuse or being raped. ${ }^{10}$ "Victims of rape have been placed in a snare. Silence is as risky as making a complaint", since it could be used against the victim as admission of illegal sexual intercourse. ${ }^{11}$ By 1988, nearly half of all women in prison were accused of zina. ${ }^{12}$

The women's movement emerged in reaction to Zia's Islamisation, particularly the Hudood Ordinances. In 1981, Shirkat Gah, a women's collective, helped to launch the Women's Action Forum (WAF), an umbrella group of women's rights activists and organisations. Its demonstrators against the evidence law were threatened, attacked and arrested. ${ }^{13}$ After Zia's 1988 death and the restoration of democracy, women and other prominent rights groups, particularly the independent Human Rights Commission of Pakistan (HRCP), played a major role in lobbying against discriminatory legislation and for greater gender equality.

Democracy's return presented opportunities for women's rights, particularly after the 1988 elections brought to power the left-of-centre Pakistan Peoples Party (PPP) of Benazir Bhutto, the first female prime minister of a Muslim country. Despite military and Islamist party pushback, a number of steps were taken in her first tenure (December 1988-August 1990) to undo some of the harm done by the Zia regime, including freeing all women charged under the Hudood Ordinances. ${ }^{14}$ Yet, lacking a stable parliamentary majority and ousted by a military-devised intervention before it completed even a second year in office, the government failed to reverse Zia's discriminatory laws. In its second tenure (October 1993-November 1996), it acceded to the UN Convention on the Elimination of All Forms of Discrimination Against Women

\footnotetext{
${ }^{9}$ The testimony of two women became equal to a man's. In financial matters, two men or a man and two women were required to attest a document. Qanun-e-Shahadat, 1984, Chapter 2, Section 17. Rubya Mehdi, The Islamisation of the Law in Pakistan (Richmond, 1994), p. 149.

${ }^{10}$ Khawar Mumtaz and Farida Shaheed, Women of Pakistan: Two Steps Forward, One Step Back (London, 1987). Crisis Group interviews, women's rights activists, Islamabad, November-December 2014.

${ }^{11}$ Jahangir and Jilani, op. cit., p. 88. In 1983, the court used the pregnancy of Safia Bibi, a blind eighteen-year-old raped by her landlord and his son, to convict her of unlawful sexual intercourse, while freeing the men for lack of evidence. Public outcry in part led the Federal Shariat (Islamic Law) Court (FSC) to reverse the lower court judgement in 1985. Mumtaz and Shaheed, op. cit., pp. 103-104. Established by the Zia regime in 1980, the FSC reviews legislation to ensure accordance with Islamic injunctions. For analysis of its functioning and rulings, see Crisis Group Report, Reforming the Judiciary in Pakistan, op. cit.

${ }^{12}$ Asma Jahangir, "What the Protection of Women Act does and what is left undone", in "State of Human Rights in 2006”, Human Rights Commission of Pakistan (HRCP), January 2006.

${ }^{13}$ Mumtaz and Shaheed, op. cit., pp. 106-107.

${ }^{14}$ Suad Joseph and Afsaneh Najmabadi, Encyclopaedia of Women and Islamic Culture: Family, Law and Politics (Leiden, 2003), p. 83.
} 
(CEDAW) and passed the Women in Distress and Detention Fund Act to provide financial and legal assistance to women in need. ${ }^{15}$

The flawed democratic transition of the 1990s, in which governments were dismissed through military-engineered interventions before completing full terms, saw further institutional curbs on women's rights and freedoms. In the three-month interim between dismissal of Bhutto's first government and installation of Nawaz Sharif's Muslim League (Pakistan Muslim League-Nawaz, PML-N) government, President Ghulam Ishaq Khan, who had been Zia's finance minister and then chairman of his rubber stamp Senate (upper house), promulgated the qisas (retribution) and diyat (monetary compensation/bloody money) ordinance. It allowed a victim's heir (wali) to pardon a killer in return for compensation, thus legitimising (even encouraging) murder, particularly "honour killings" of women. ${ }^{16}$ Since most "honour" crimes are committed within the family, the victim's relatives often forgive the perpetrator under the diyat provision. ${ }^{17}$ Instead of addressing such legal distortions, the new government made the ordinance part of the Pakistan Penal Code in $1997 .{ }^{18}$

General Pervez Musharraf, who overthrew Nawaz Sharif's government in October 1999, promised to end religious extremism and promote "enlightened moderation". ${ }^{19}$ Yet, dependent on Islamist parties to counter his moderate political opposition, his regime did not reverse Zia's discriminatory laws. ${ }^{20}$ It did set up the National Commission on the Status of Women (NCSW) in 2000 but did not act on its recommendation to repeal the Hudood Ordinances. ${ }^{21}$ In 2006, civil society successfully lobbied parliament to pass the Protection of Women Act (PWA), returning rape from those ordinances to the Penal Code.

By separating zina from zina-bil-jabr, the PWA prevented rape charges from being converted into charges of extramarital sexual intercourse. ${ }^{22}$ Filing a complaint against rape was no longer risky. ${ }^{23}$ However, the amended Hudood Ordinances retained "the roots of religious extremism" and discrimination by still criminalising

\footnotetext{
${ }^{15}$ Among other provisions, CEDAW binds signatory states to promote gender equality "in their legal system, abolish all discriminatory laws, and adopt appropriate ones prohibiting discrimination against women". Text at www.un.og/womenwatch/daw/cedaw/cedaw.htm. "Women in Distress and Detention Fund Act”, National Assembly Secretariat, Islamabad, 15 October 1996.

${ }^{16}$ Maliha Zia Lari, "A pilot study on 'honour killings' in Pakistan and compliance with law”, Aurat Foundation, November 2011; Mumtaz and Shaheed, op. cit., pp. 110-111.

17 "State of Human Rights in 2013", HRCP, March 2014, p. 180; Neha Ali Gauhar, "Honour crimes in Pakistan: Unveiling reality and perception", Community Appraisal and Motivation Program (CAMP), 2014.

18 "Crime or custom? Violence against women in Pakistan", Human Rights Watch, August 1999, p. 25.

${ }^{19}$ Musharraf's "strategy of enlightened moderation", in his words, called for countering violent extremism through "poverty alleviation, education, health and social justice". Justice, he wrote, "must be done and seen to be done". Pervez Musharraf, "Islam and West: Time for enlightened moderation”, The Khaleej Times, 2 June 2014.

${ }^{20}$ Crisis Group Asia Reports $\mathrm{N}^{\circ} 49$, Pakistan: the Mullahs and the Military, 20 March 2003; and $\mathrm{N}^{\circ} 73$, Unfulfilled Promises: Pakistan's Failure to Tackle Extremism, 16 January 2004.

${ }^{21}$ Crisis Group Report, Reforming the Judiciary in Pakistan, op. cit. Some provisions were revised.

22 "Struggle for justice", Dawn, 12 February 2015.

23 In 2010, the FSC ruled that sections of the PWA violated Islamic provisions because they "annulled the overriding effect of the Hudood Ordinances". "Protection of Women (criminal law amendment) Act, 2006”, Government of Pakistan, December 2006; text of Federal Shariat Court ruling, 2010, at www.federalshariatcourt.gov.pk.
} 
zina and allowing testimony only by Muslim males in Hadd cases, reinforcing "the impression that women and non-Muslims are inferior citizens". ${ }^{24}$

Musharraf's Legal Framework Order (LFO) ${ }^{25}$ set a 17 per cent quota for women in the Senate, National Assembly (lower house) and provincial assemblies, considerably increasing their numbers. ${ }^{26}$ With the exception of the PWA, however, this did not immediately translate into more pro-women laws. Indeed, the regime's support for Islamist political parties led to reinforced state-sanctioned gender discrimination. ${ }^{27}$

In 2003, the MMA-controlled NWFP legislature passed a law declaring Sharia the province's supreme law and empowering its government to set up commissions to examine ways to Islamise education, the economy and legal system. In 2005, it passed the Hisba bill - eventually struck down by the Supreme Court - to ensure enforcement of Islamic codes of conduct. ${ }^{28}$ While the military's peace deals following failed operations in FATA allowed violent extremists to further expand their influence in the tribal belt, the MMA's political clout resulted in the unregulated expansion of jihadi madrasas in both NWFP and Balochistan, further undermining women's security in the Pashtun heartland. ${ }^{29}$

Musharraf's ouster, the restoration of democracy and elections in 2008 and 2013 marginalised the Islamist parties and brought first the centre-left PPP and then the centre-right PML-N to power. Democracy's return raised hopes that the state would proactively protect and empower women. Yet, progress on women's laws and protections has been limited.

\section{B. The State's Failure to Protect}

Parliament's unwillingness to repeal or even reform discriminatory laws, the absence of a national domestic violence law and a gender-insensitive, dysfunctional criminal justice system are significant factors in the state's failure to protect women from en-

\footnotetext{
${ }^{24}$ Jahangir, op. cit. A woman still cannot give evidence in Hadd cases, and the accused must be a non-Muslim for the testimony of non-Muslims to be accepted.

${ }^{25}$ The LFO was primarily aimed at regime consolidation, expanding presidential powers and tilting the political playing field toward Musharraf's civilian proxies and allies. "Legal Framework Order 2002”, August 2002. Crisis Group Asia Reports No 40, Pakistan: Transition to Democracy?, 3 October 2002; and $\mathrm{N}^{\circ} 102$, Authoritarianism and Political Party Reform in Pakistan, 28 September 2005 .

${ }^{26}$ This quota was for "reserved" seats, allocated to political parties in proportion to their total directlyelected "general" seats in the federal and provincial parliaments. Article 51, constitution of Pakistan. After the quota was introduced, the percentage of women in the federal parliament increased from 2.3 to 22.5 per cent. Muhammad Rashid Mahfooz Zaka, "Gender Equality and Women's Empowerment in Parliament”, in "Gender, Peace and Conflict Research in Pakistan”, Journal of Peace, Conflict and Development, no. 19, December 2012, p. 20.

${ }^{27}$ The rigged 2002 elections produced a Muttahida Majlis-e-Amal (MMA) government in KPK (then Northwest Frontier Province, NWFP) and a coalition government with Musharraf's Muslim League (Muslim League - Quaid-i-Azam - PML-Q) in Balochistan. The MMA was a six-party Islamist alliance. Crisis Group Reports, Mullahs and the Military; and Appeasing the Militants, both op. cit. ${ }^{28}$ Crisis Groups Report, The Militant Jihadi Challenge, op. cit.

${ }^{29}$ Propagating religious and sectarian hatred, jihadi madrasas have flourished, filling the gaps of a dilapidated public education sector and providing an endless stream of recruits to extremist organisations. Crisis Group Asia Reports $\mathrm{N}^{\circ} 257$, Education Reform in Pakistan, 23 June 2014; $\mathrm{N}^{\circ} 95$, The State of Sectarianism in Pakistan, 18 April 2005; No84, Pakistan: Reforming the Education Sector, 7 October 2004; and $\mathrm{N}^{\circ} 36$, Pakistan: Madrasas, Extremism and the Military, 29 July 2002.
} 
demic violence. According to the latest Pakistan Demographic and Health Survey, 39 per cent of fifteen- to 49-year-old married women have been physically or emotionally abused by their spouse; one in ten women experienced violence during a pregnancy; and 52 per cent of women who experienced violence kept it secret. ${ }^{30}$ In 2014 , according to the HRCP, 232 women suffered acid attacks or were burned, the majority by someone they knew; 859 committed suicide, often due to domestic abuse; and 461 were killed by their husbands. ${ }^{31}$ In 2014, 898 were victims of "honour killings". ${ }^{2}$ Because the law protects those responsible, women are murdered with impunity by family or community members for reasons ranging from marrying for choice, financial motives or being raped.

The dysfunctional criminal justice system, compounded by lack of gender responsiveness, ensures that perpetrators are seldom held accountable. ${ }^{33}$ Few survivors of gender-based violence go to the police; when they do, many cases are not even registered. Female complainants are often dismissed or put in harm's way by officers trying to mediate, and some officers have assaulted a complainant. ${ }^{34}$ The police are illequipped to handle gender-violence cases, particularly due to inadequate numbers of women officers, but simply raising numbers would be insufficient unless accompanied by enhanced authority, training and stringent oversight, since there are institutional biases to be overcome, and policewomen have also been known to commit abuses. There is also urgent need to improve the entire force's technical capacity. ${ }^{35}$

Evidence collection, currently "a male-dominated area", is particularly poor.$^{36}$ Timely medical examinations in rape cases are seldom conducted, resulting in weak court cases and poor conviction rates. Of the 14,580 cases registered between 2009 and late 2014 nationally, only 949 (6.5 per cent), led to convictions. In Sindh, 38 (3.5 per cent) of 1,077 cases and in the federal capital Islamabad one of 90 led to convictions. ${ }^{37}$

While investigation and prosecution agencies are poorly equipped and trained to build strong criminal cases, judicial bias also sometimes leads to verdicts that penalise women. "While researching on knowledge, attitudes and practices on rape, I was shocked to hear a [lower court] judge in Punjab say that if it was a gang rape, it could

30 “2012-13 Pakistan Demographic and Health Survey”, National Institute of Population Studies, December 2013, p. 219. The findings do not include FATA.

${ }^{31}$ Figures given to Crisis Group by HRCP, Lahore, February 2015. Between 2007 and March 2014, more than 1,000 acid-attack cases were reported, overwhelmingly on women and children. Acid Survivors Foundation (a Pakistani NGO founded in 2006), acidsurvivorspakistan.org.

$3^{2}$ Data provided to Crisis Group by HRCP, Lahore, February 2015.

33 Police apathy over violence against women, often seen as internal family matters, was apparent when officers looked on as a young pregnant woman, married of her free will, was stoned to death by male family members in front of the Lahore High Court. In November 2014, that court gave the death penalty to her father, a brother, a cousin and the man chosen by the family to marry her. "Woman stoned to death outside Lahore High Court", Reuters, 27 May 2014; "LHC announces death penalty for Farzana's murderers", Dawn, 19 November 2014.

${ }^{34}$ In May 2010, female officers in a Punjab police station brutally beat a woman in an attack caught on video but were acquitted because the victim denied the incident, presumably under pressure. Crisis Group Report, Reforming Pakistan's Criminal Justice System, op. cit.

${ }^{35}$ Crisis Group Asia Report, $\mathrm{N}^{\mathrm{0}} 157$, Reforming Pakistan's Police, 14 July 2008.

${ }^{36}$ Crisis Group interview, Ihsan Ghani, director general, National Police Bureau, Islamabad, 17 September 2014.

37 "Seeking justice: only one rape conviction in the last five years", The Express Tribune, 9 November 2014 . 
be considered zina-bil-jaber (rape). But if there was only one aggressor, then it was zina (consensual extramarital sex)", a gender expert said. ${ }^{38}$

Some efforts are being made to improve performance on gender-based violence. The National Police Bureau (NPB), an umbrella body tasked with implementing reform and monitoring progress, created a gender crime cell to document crimes against women and advise provinces on standard procedures to deal with victims of gender-based violence and investigate violent crimes against women. ${ }^{39}$ It has also, as part of a German government-funded Gender Responsive Policing project, drawn up a strategy that includes training and more policewomen..$^{40}$ While the heads of all provincial police endorse the strategy, interactions with the NPB and most importantly NPB capacity to influence policy remain limited. ${ }^{41}$

Since 2006, the National Police Academy's curriculum includes a training module developed by Rozan, an Islamabad-based NGO, to increase police sensitivity to women's rights and needs, and a training manual for investigation officers on interviewing women and child survivors of violence. ${ }^{42}$ Sensitising will, however, be insufficient if officers are not held accountable for failing to investigate the crimes, the superior judiciary does not hold the subordinate judiciary accountable for failing to give justice to women survivors of violence, and discriminatory laws stay on the books. The onus rests on elected governments and parliaments to ensure that women's security is not sacrificed to political expediency.

\footnotetext{
${ }^{38}$ Crisis Group interview, Naghma Imdad, Islamabad, 6 February 2015.

39 Crisis Group interview, Ihsan Ghani director general, NPB, Islamabad, 17 September 2014. "Standard operating procedures for police for dealing with women and investigating crimes of violence against women”, NPB, interior ministry, November 2008.

40 "Equality in perspective - gender strategy of police 2012-2016", Gender Responsive Policing Project and NPB, 2012.

41 "Since the Police Order 2002, we should have held 24 biannual board meetings, but we've only held seven. The bureau lay dormant for years, losing relevance in the eyes of the political leadership", its current head said. Crisis Group interview, Ihsan Ghani, director general, NPB, Islamabad, 17 September 2014. On Police Order 2002, see Crisis Group Report, Reforming Pakistan's Police, op. cit.

${ }^{42}$ Crisis Group interview, Sayyed Safi Peerzada, coordinator, Rozan's Rabta (contact) police program, Islamabad, 12 December 2014. Created in 1998, Rozan focuses on countering violence against women and children, especially psychological and sexual abuse.
} 


\section{Women and the Democratic Transition}

\section{A. Legislative Gains: Two Steps Forward, One Back}

Eight years into the democratic transition, there has been some progress in empowering and protecting women, particularly via progressive legislation. ${ }^{43}$ The appointment of Dr Fehmida Mirza in 2008 as the first woman to hold the highest post - speaker in the national legislature "contributed immensely to promoting a women-friendly and gender-sensitive political culture [in parliament]" ${ }^{44}$ The formation of the crossparty-lines Women's Parliamentary Caucus (WPC) in 2009 with UN Development Programme (UNDP) aid was particularly significant. United for a common cause and helped by rights activists in researching and drafting bills, women parliamentarians achieved a number of pro-women laws. ${ }^{45}$ "The caucus is a watershed. This is the first of its kind in Pakistan's political history", said the WPC secretary Syed Shamoon Hashmi, who called it "a mechanism that has enabled quantitative and qualitative input for women in the proceedings of the House". ${ }^{46}$

The 2012 National Commission on the Status of Women (NCSW) Act transformed that commission into a powerful and autonomous body. The status of the chair, appointed by the prime minister in agreement with the opposition leader, is equivalent to that of a minister of state. The NCSW is tasked with reviewing government policies and legislation to ensure gender equality and women's empowerment. It can investigate violations with "the powers vested in a civil court ... for enforcing the attendance of any person and compelling the production of documents" ${ }^{47}$ The chair also is to sit on the Pakistan National Commission for Human Rights (PNCHR), which, however, almost three years after it was established, is yet to be formed. In February 2015, the government finally appointed its members, but it will begin to function only after the president approves its composition..$^{8}$

In 2010, the PPP-led parliament passed the Protection against Harassment of Women at the Workplace Act, with complaint mechanism, inquiry procedure and penalties to improve working-women's conditions and increase their presence in the labour force; and the Criminal Law (amendment) Act inserted sexual harassment into the Penal Code. The 2011 Prevention of Anti-Women Practices Act bars forced marriages, marriages to the Quran, giving away women in vani or swara or depriving them of inheritance, ${ }^{49}$ and provincial governments from suspending, remitting or

\footnotetext{
${ }^{43}$ Crisis Group Asia Report $\mathrm{N}^{\circ} 249$, Parliament's Role in Pakistan's Democratic Transition, 18 September 2013.

${ }^{44}$ Naeem Mirza, "Seven pro-women laws in seven years", Legislative Watch, Aurat Publication and Information Service Foundation, Newsletter Issue no. 38, December 2011. Aurat Foundation, created in 1986, is an Islamabad-based NGO with a focus on women's empowerment. A women's rights activist noted that "women were finally experiencing power in the House". Crisis Group interview, Marvi Sirmed, Islamabad, 6 November 2014.

${ }^{45}$ Of eighteen private member bills in the 2008-2012 parliament, twelve were introduced by women. Zaka, op. cit., p. 28.

${ }^{46}$ Crisis Group interview, Syed Shamoon Hashmi, Islamabad, 25 September 2014.

47 "National Commission on the Status of Women Act, 2012", NCSW, www.ncsw.gov.pk.

${ }^{48}$ National Commission for Human Rights Act, 2012; "Rights commission set up, to become operational soon", Dawn, 14 February 2015.

${ }^{49}$ Giving away women, mainly minors, to settle disputes is vani in Punjabi, swara in Pashtu. Marrying to the Quran is usually to keep a woman's inheritance in the family.
} 
commuting punishments in rape cases. A women's rights NGO noted: "The biggest success ... of this legislation" was acceptance that "crimes committed against women under the guise of 'customary practices' are in actuality crimes". ${ }^{\circ}$ Also in 2011, the Criminal Law (second amendment) Act, made attacks with a substance such as acid punishable from fourteen years to life imprisonment and a minimum million rupee (nearly $\$ 10,000$ ) fine..$^{51}$ Reporting of attacks and registration of such cases has increased, and sentences have become harsher..$^{2}$

The failure of some provincial governments to follow the federal lead, however, has hampered justice delivery, particularly since responsibilities of the federal women's affairs ministry were devolved to the provinces under the eighteenth constitutional amendment (2010). ${ }^{53}$ Unlike Sindh and Punjab, Balochistan and KPK have yet to appoint ombudspersons to deal with workplace harassment. ${ }^{54}$ The PML-N, despite a comfortable federal parliament majority, has not championed women's rights. ${ }^{55}$ PPP opposition parliamentarians are mainly responsible for introducing private member bills to enhance protection for women. ${ }^{56}$

One such private member bill, endorsed by the Senate standing committee on law and justice in January 2015, would preclude any out-of-court blood-money settlement for honour killings. In February, that committee endorsed a bill that, inter alia, would make use of DNA evidence standard in rape cases, tighten checks on medicallegal officers, enhance punishments, require courts to decide the cases within six months and prohibit judges from considering the victim's character. In January 2015, the Senate standing interior committee endorsed a bill to require a life imprisonment sentence and three million rupee fine (nearly $\$ 30,000$ for custodial death or rape and prohibit women being taken into custody by male security personnel or

\footnotetext{
${ }^{50}$ Maliha Zia Lari, "A critical appreciation of the Prevention of Anti-Women Practices (Criminal Law amendment) Bill 2011", Legislative Watch, Aurat Publication and Information Service Foundation, Newsletter Issue no. 37, August-mid-November 2011.

${ }^{51}$ In the 232 cases of violent attacks on women in 2014, acid was used in 92, fire in 67. Data shared by HRCP with Crisis Group, February 2015.

$5^{2}$ Before 2011, the average sentence was six to ten years of imprisonment; in 2013 it was twenty years. Caroline Bates and Valerie Khan, "Acid Violence - Fostering effective implementation of prowomen and girls laws: Criminal Law Amendment Act 2011 (Act XXV) - an example of good practice", Acid Survivors Foundation, April 2014.

${ }^{53}$ Removing the distortions of military rule and restoring federal parliamentary democracy, the eighteenth constitutional amendment devolved significant power from the centre to the provinces, addressing a longstanding faultline that had largely contributed to the country's dismemberment in 1971. Crisis Group Report, Parliament's Role in Pakistan's Democratic Transition, op. cit.

54 "Pro-women legislation", Dawn, 15 November 2014. The federal ombudsman secretariat has proposed amending the law to clarify the definition of "workplace" to include home-based workers and students in educational institutions; extend its application to men facing harassment at the workplace; and give the secretariat power to act on its own initiative (suo moto). "Anti-harassment law needs teeth", The Nation, 23 February 2015.

${ }^{55}$ See, for instance, "Pakistan Vision 2025", the PML-N government's long-term plan to promote human, social and economic development. Planning, development and reform ministry, www.pc.gov.pk. Also, "Parties vow to improve women's status", The News, 30 September 2014.

${ }^{56}$ The opposition-controlled Senate has passed three such bills. "Senate approves criminal laws, Privatisation Commission amendment bills", The News, 3 March 2015. The PML-N government's commitment will be judged when the lower house votes on the bills.
} 
detained by law enforcement or intelligence agencies to obtain information about an alleged criminal. ${ }^{57}$

While passage of these bills would be positive, the Hudood Ordinances would continue to undermine women's rights. So long as consensual extramarital sexual intercourse is a criminal offence, use of DNA evidence could even endanger women: "If an unmarried woman gets pregnant, she might claim she was raped [to avoid a charge of zina], but she won't want her partner to be punished. With a DNA test, the father's identity would be known; they would both end up in jail". ${ }^{8}$

The moderate parties' apparent unwillingness to repeal or revise laws justified by Islamists on religious grounds is largely responsible for the Hudood Ordinances' retention. Islamist opposition also caused the Domestic Violence Bill (2009) to fail, because it was not introduced in the Senate within three months after National Assembly passage. A leader of the largest Islamist party, JUI-F (Jamiat Ulema-e-Islam-Fazlur Rehman), and chair of the Council of Islamic Ideology, Senator Maulana Mohammad Khan Shehrani, said, "we oppose this law because it is not the solution; rather it is a possible cause of more chaos in society". 59

Though there is no national law against domestic violence, some progress has been made in the provinces. Balochistan passed such a law in 2014; Sindh did so in 2013 but has yet to follow up with rules and protection committees. ${ }^{60}$ Punjab appears about to adopt a bill, a ruling party legislator said, but in KPK, an opposition politician said, one was still "stuck with the law department". ${ }^{61}$

\section{B. Political Empowerment}

The Election Laws (Amendment) Act 2011 made voter registration contingent on possession of a computerised national identity card (CNIC) issued by the National Database and Registration Authority (NADRA). With CNIC issuance to women a priority, electoral rolls included 86 per cent of eligible women voters in 2012, compared to 50 per cent in 2008..$^{62}$ The increase can also partly be explained by the Benazir Income Support Program (BISP), a national social safety measure the PPP government launched in 2008. It gives a monthly stipend to female heads of household subsisting on less than 6,000 rupees (around \$60) a month. A CNIC is required for BISP

\footnotetext{
${ }^{57}$ Crisis Group interview, Senator Sughra Imam (who introduced the first two bills), 11 March 2015. Senator Farhatullah Babar introduced the third. "The fight against rape”, The Express Tribune, 24 January 2015; "Senate body adopts two bills on honour killing, rape", The Nation, 22 January 2015. "Senate panel okays bill seeking life term for custodial killing", Dawn, 22 January 2015.

${ }^{58}$ Crisis Group interview, Asma Jahangir, Supreme Court Bar Association president and prominent human rights lawyer, Lahore, 13 February 2015.

59 "Pakistan edges close to domestic violence bill", Daily Times, 9 April 2010; "Two women abused an hour in Pakistan”, The Express Tribune, 2 August 2010. The Council of Islamic Ideology is constitutionally mandated to advise the legislature on the conformity of laws to Islamic injunctions. Its website is www.cii.gov.pk.

60 "Coordinated efforts stressed for effective implementation of Domestic Violence Act", press release, NCSW, 17 December 2014; "Sindh passes domestic violence bill”, The Express Tribune, 8 March 2013.

61 "International women's day: Events highlight women's achievements, issues", The News, 9 March 2015.

62 "Pakistan votes", NADRA and ECP, Government of Pakistan, April 2013, p. 31; Tariq Malik, "Technology in the service of development: the NADRA story", Center for Global Development, November 2014. Malik was the former NADRA chairperson.
} 
registration. ${ }^{63}$ Women voters in FATA and KPK, where female mobility is most restricted, also increased because of the displacement of hundreds of thousands from inaccessible and insecure areas to urban centres and relief camps due to militant violence, military operations and floods ${ }^{64} \mathrm{~A} \mathrm{CNIC}$ is needed to register as a displaced person and so gain access to resulting goods and services. Women who obtain them become eligible voters. ${ }^{65}$

It remains a challenge, however, for women to win elections. Only eight won direct seats in 2013, ten fewer than in the 2008 National Assembly polls. ${ }^{66}$ Had there been no reserved seats, female presence in the national legislature would have been minimal. Yet, because women in reserved seats lack a constituency, they often find it difficult to obtain the support of their parties and male colleagues. Some will only introduce a bill co-sponsored by influential men. Nevertheless, women elected to reserved seats have been responsible for initiating some of the most progressive legislation, including several of the bills discussed above. If the National Assembly and Senate rules of procedure are amended to allocate chairs of some key committees to women, their policy role would be strengthened and parties given incentive to choose strong women candidates.

Some parties seek to improve the direct-election chances for their women members. The ANP has awarded reserved seats to women from constituencies it narrowly lost so they can build a voter base for a future election. ${ }^{67} \mathrm{~A}$ pending private-member National Assembly bill introduced by PPP women in 2013 would make it mandatory for parties to award women at least 10 per cent of their general seat tickets. ${ }^{68}$ Though the National Assembly standing committee on parliamentary affairs approved the bill in November 2014, a co-sponsor said there is little buy-in beyond the PPP. ${ }^{69}$

Even if the bill becomes law, parties could still give women tickets to contest only constituencies they were unlikely to win. ${ }^{70}$ This could be avoided by allocating a quota of general seats for women, so that the most reluctant parties would have to nominate female candidates or lose seats in parliament. Rights activists have long sought

\footnotetext{
63 Initially Rs. 1,000 ( $\$ 10-\$ 11)$, the stipend was increased in 2014 to Rs. 1,500 ( $\$ 15)$. By late 2014, 4.7 million households were benefitting. BISP website at www.bisp.gov.pk.

${ }^{64}$ Crisis Group Asia Reports, $\mathrm{N}^{\circ} 237$, Pakistan: No End to Humanitarian Crises, 9 October 2012; $\mathrm{N}^{\circ} 227$, Aid and Conflict in Pakistan, 27 June 2012; and Briefings, $\mathrm{N}^{\circ} 111$, Pakistan: The Worsening IDP Crisis, 16 September 2010; and $\mathrm{N}^{\circ} 93$, Pakistan's IDP Crisis: Challenges and Opportunities, 3 June 2009.

65 "Voices from FATA - Women in FATA elections 2013", Community Appraisal and Motivation Programme (CAMP), May-June 2013.

${ }^{66}$ Election Commission of Pakistan (ECP) website, www.ecp.pk.

${ }^{67}$ Crisis Group interview, Bushra Gohar, ANP senior vice president, Islamabad, 1 December 2014.

${ }^{68}$ Political Parties Order (Amendment) Bill, 2013, private members (Nafisa Shah and Azra Pechuho) draft.

69 “Parties don't want to be seen against it, but no one's going to push for it, and that's why it has still not been subject to a vote in the House. If this law doesn't pass, we will have to look into other measures for women to build electoral constituencies". Crisis Group telephone interview, Nafisa Shah, 18 February 2015. Her co-sponsor, Pechuho, is former president and PPP leader Asif Ali Zardari's sister, indicating high-level party support.

70 "Empowering women for stronger political parties - a good practices guide to promote women's political participation”, UNDP and National Democratic Institute, October 2011, pp. 22-27.
} 
a 33 per cent minimum quota in the National Assembly, to create a "critical mass" to influence male counterparts and produce change. ${ }^{71}$

The pending bill discussed above would also require parties to ensure a 33 per cent minimum quota in elected general councils and committees. However, quotas would be challenging. A gender expert and women's rights activist cautioned:

All these measures, including reserved seats, are a means to an end until such affirmative action is no longer needed .... Raising women's presence in the political realm will not necessarily lead to greater gender equity without supporting women's right to franchise so that women voters are no longer considered marginal, and women and men vying for their support can then be elected on a pro-women agenda. $^{72}$

As noted, the eighteenth constitutional amendment devolved subjects from the federal women's affairs ministry to the provinces. The Provincial Commissions for the Status of Women (PCSWs) are mandated to review provincial legislation and policies to promote empowerment, ensure gender equality and counter discrimination. Punjab's PCSW can also exercise civil-court powers to investigate complaints. ${ }^{73}$ With access to grassroots networks, the PCSWs could respond faster to abuses than the NCSW. But provincial response has been uneven. Balochistan still lacks a PCSW; the bill to establish one in Sindh was introduced only in March. Where PCSWs have been formed (Punjab and KPK), they lack sufficient resources and political backing to fulfil their mandate. ${ }^{74}$

This deficiency is particularly evident in KPK. Its PCSW, established in 2009, still has inadequate staff and political support. A member said, "as a women's body, we are not taken seriously, neither by the previous [KPK] government, nor the present one". ${ }^{75}$ Unlike Punjab's PCSW, formed in 2014 as an autonomous body ${ }^{76}$ KPK's operates under the provincial social welfare, education and women empowerment ministry. Though the ministry has been generally supportive, its ability to influence government policy is limited: its head has been reduced from status of minister to that of special assistant to the chief minister. ${ }^{77}$

Women activists are concerned that even rights gained could be undermined in KPK, where the Pakistan Tehreek-e-Insaf (PTI) is in coalition with Jamaat-i-Islami (JI). The previous ANP-led government passed important pro-women laws, such as one in 2011 to protect property inheritance rights. The PTI-JI alliance seems to have little interest in such actions. A woman PTI member in the province said, "I completely dissociate myself from the party when it comes to women's issues" ${ }^{78}$ Yet, women are the worst affected by conflict in KPK and neighbouring FATA and most in need of protection and empowerment.

\footnotetext{
${ }^{71}$ Crisis Group interviews, rights activists, NGO and political party workers, Islamabad, Peshawar, Lahore, July 2014-February 2015.

${ }^{72}$ Crisis Group interview, Islamabad, 15 February 2015.

${ }^{73}$ The Punjab Commission on the Status of Women Act 2014.

74 "We [and PCSWs] do not have enough resources to deal with the impact of conflict on women". Crisis Group interview, Khawar Mumtaz, NCSW chair, Islamabad, 19 December 2014.

${ }^{75}$ Crisis Group interview, Peshawar, September 2014.

${ }^{76}$ Punjab Commission on the Status of Women Act 2014.

77 Crisis Group interviews, PCSW members, Peshawar, July 2014.

${ }^{78}$ Crisis Group interview, Peshawar, September 2014.
} 


\section{Political Empowerment and Justice for Women in Conflict Zones}

\section{A. Silencing Women's Voices \\ 1. Political participation in FATA}

Even the few laws that protect women do not extend to FATA. ${ }^{79}$ An administrative and legal framework, codified in the 1901 colonial Frontier Crimes Regulations (FCR), denies its citizens in FATA constitutionally guaranteed fundamental rights and impartial justice. ${ }^{80}$ Following the latest attempt to reform the FCR, then President Zardari's August 2011 reform package, women and children under sixteen can no longer be detained under the FCR's collective responsibility clause, which empowers an agency's top bureaucrat, the political agent, to arrest family members (even an entire tribe) for crimes committed by an individual. ${ }^{81}$ Yet, women still suffer indirectly from the collective and preventative detention clauses when husbands and older sons, usually the sole wage earners, are detained.

FCR also denies FATA residents political rights enjoyed by all other citizens. Adult franchise was granted only in 1996 by Benazir Bhutto's government. Political party activity was curtailed until August 2011, when her widower, President Zardari, extended the Political Parties Order (2002) to the region. Yet, FATA parliamentarians, who have been directly elected to the National Assembly since 1997, still cannot legislate on FATA. ${ }^{82}$

Even the limited political freedoms, such as franchise, are under attack by violent extremists, with women often the prime targets. In the 2008 elections, militants prevented a third of FATA women from voting. ${ }^{83}$ In Khyber agency, the radical Sunni Lashkar-e-Islami intimidated local officials, candidates and the electorate, especially women, who were "banned" from voting. ${ }^{84}$ In South Waziristan agency, elections were not held due to the deteriorating security environment. When polls did take place in the conflict-hit agency in 2013, the 11.37 per cent turnout was the lowest in the country. ${ }^{85}$

Prior to election day 2013, the NCSW received complaints that women were being barred from voting in much of FATA.$^{86}$ Militants distributed pamphlets in North Waziristan agency warning tribesmen against allowing women relatives to vote; in

\footnotetext{
${ }^{79}$ FATA has seven administrative units or agencies (Bajaur, Orazkai, Mohmand, Khyber, Kurram, North Waziristan and South Waziristan), and Tribal Areas, also known as Frontier Regions, adjoining KPK's Peshawar, Kohat, Bannu, Dera Ismail Khan, Lakki and Tank districts.

${ }^{80}$ Crisis Group has called for FCR's repeal. Crisis Group Reports, Reforming Pakistan's Criminal Justice System; Countering Militancy in FATA; and The Militant Jihadi Challenge, all op. cit.

${ }^{81}$ KPK's governor has executive authority over FATA as the president's representative. Political Agents are federal bureaucrats. Crisis Group Report, Countering Militancy in FATA, op. cit.

${ }^{82}$ Article 247 (3): "No act of Parliament shall apply to FATA or any part thereof unless the president so directs". The president has discretion to issue regulations with respect to the "peace and good governance" of FATA; federal parliament laws only apply if the president so orders.

83 "Poll doors closed on a third of FATA women", Daily Times, 17 February 2008.

84 "Elections 2008: Will Taliban get access to the parliament?", Pakistan Institute for Peace Studies, 13 December 2007.

85 "State of Human Rights in Pakistan 2013", op. cit., p. 153.

${ }^{86}$ Khawar Mumtaz, NCSW chairperson, "Report on elections monitoring with recommendations", 23 June 2013.
} 
the agency capital, Miramshah, clerics made similar announcements on mosques' loudspeakers. ${ }^{87}$ In the run-up to the first party-based polls in the region, the elevenmember Political Parties Joint Committee on FATA Reforms, including the PPP, ANP and PTI, recommended reserved National Assembly seats for FATA women and called on the ECP (Election Commission of Pakistan) to ensure that polling stations for women were set up in all FATA agencies and Frontier Regions. When, braving insurgent threats, women tried to vote in large numbers in Khyber agency, however, there were insufficient booths. ${ }^{88}$

The right to vote and contest public office will translate into political empowerment of FATA women only if far more is done by the ECP to facilitate women voters and by the state to protect them, as well as women candidates and polling stations. The ECP should investigate all cases where women have been prevented from voting. In Bajaur agency, Badam Zari, an independent candidate and the first FATA woman to contest national elections, ${ }^{89}$ obtained only 142 of 185,040 votes, amid reports that local strongmen and clerics had dissuaded communities from voting for a woman and from letting women cast ballots. Only 2,890 of the 120,230 women on the agency's electoral roll participated. ${ }^{90}$

\section{Political participation in KPK}

Women in KPK, unlike FATA, have constitutional freedoms and legal protections, though the Provincially Administered Tribal Areas (PATA) is something of an exception. PATA is subject to Pakistan's basic criminal and civil law framework and is under the jurisdiction of the provincial KPK legislature (and the National Assembly) and the Peshawar High and Supreme Courts. However, under Article 247 of the constitution, laws apply there only if specifically extended by the governor (the federation's representative), with presidential consent. ${ }^{91}$

In PATA and the rest of KPK, violent extremists target women, whose rights are also under siege by Islamist parties. Most mainstream parties make little effort to advance political empowerment, particularly through the ballot box. In 2013, the number of women candidates to the KPK provincial assembly increased from eleven in 2008 to twenty-six. Yet, sixteen stood as independents, without party backing or financial and logistical support. ${ }^{92}$ Only five of eighteen women candidates for KPK's National Assembly general seats had party backing. Even a woman such as Nusrat Begum, the first from Lower Dir district to contest a National Assembly seat and the district vice president of the PTI, the party that swept the KPK polls, was an independent candidate. ${ }^{93}$ Unsurprisingly, she and Musarrat Shaheen, a well-known Pashtun

\footnotetext{
87 "Voices from FATA", op. cit.; “Taliban, taboos bar millions of women from voting”, Agence FrancePresse, 25 April 2013.

88 "Political parties campaign in historic FATA elections", Political Parties Joint Committee on FATA Reforms, press release, 14 March 2013; "Voices from FATA", op. cit.

89 "Badam Zari vows to project soft image of tribal areas", Dawn, 2 April 2013.

90 "Final electoral rolls 2012 - voter stats district wise (FATA)", ECP; "Voices from FATA”, op. cit.

${ }^{91}$ Crisis Group Report, Countering Militancy in PATA, op. cit.

92 Maliha Zia, “2013 elections - women's representation in legislatures”; Wasim Wagha, "Number of women candidates rises sharply in 2013 elections", both in Legislative Watch, Aurat Publication and Information Service Foundation, newsletter no. 41, March-November 2013.

93 "Two tribal women, Badam Zari and Nusrat Begum, out to make history", Dawn, 1 April 2013.
} 
actress who competed against JUI-F leader Maulana Fazlur Rahman, received less than 200 votes each..$^{94}$

In a number of polling stations, including in Upper and Lower Dir, Buner, Mardan, Dera Ismail Khan, Nowshera, Batagram and Malakand districts, men from almost all parties agreed to bar women, including party supporters, from voting. Male provincial assembly candidates in Upper Dir agreed a signatory would be fined ten million rupees (some $\$ 100,000$ ) to be paid to the jirga (council of elders) in case of non-compliance. Only one woman voted there and none in six polling stations in Lower Dir, where in that district's Ouch union council, candidate Begum was the sole woman voter. ${ }^{95} \mathrm{~A}$ poll monitor said, "we alerted the ECP about women being barred from voting. Its provincial office wrote back saying it had conducted an inquiry in Lower Dir and found no evidence". ${ }^{96}$

After proof of similar agreements surfaced during by-elections, the Peshawar High Court demanded that the ECP withhold results where women's vote was negligible and recommended amendments to the Representation of the People Act 1976 to include punitive action against those responsible. ${ }^{97}$ The Supreme Court overturned this ruling, allowing the ECP to validate results. ${ }^{98}$

Civil society activists have called for a minimum 10 per cent turnout of registered women voters to validate results in any constituency. KPK's PCSW recommended to the ECP - so far unsuccessfully - that results in a constituency should be considered valid only if the turnout was at least 20 per cent female. ${ }^{99}$ A private member National Assembly bill introduced in 2014 and pending would have the ECP annul elections in "any constituency [where] the women voters have been constrained by any means to cast their votes". ${ }^{100}$ Though forcibly preventing women from voting is already a crime, and the ECP must act on credible evidence, parties have yet to move against candidates and supporters who entered into agreements to prevent women from voting, such as in Lower Dir district. ${ }^{101}$

KPK women have braved threats to vote and stand for office, including Najma Hanif Jadoon, a human rights activist and ANP candidate for a reserved provincial assembly seat who was shot dead in Peshawar in August 2013. ${ }^{102}$ Ahead of that month's by-elections in Hangu district, the Pakistani Taliban distributed pamphlets warning

\footnotetext{
94 “All women candidates from KP lost elections by huge margins", The News, 23 May 2013.

95 Upper and Lower Dir belong to PATA. "GEM mission urges ECP to declare polls null, void”, Aurat Foundation's Gender Election Monitoring Mission with Gender Concern International, Election Monitoring 2013, Aurat Foundation, 14 May 2013; "KP govt confirms women vote blocked by political parties", Dawn, 10 May 2014; "More agreements surface barring women from voting”, Dawn, 16 May 2014.

${ }^{96}$ Crisis Group interview, PCSW member and Aurat Foundation representative, Peshawar, July 2014. She added that the ECP "also said that it could request people to vote but not force them".

${ }^{97}$ The law guides the conduct of elections to the national and provincial assemblies.

98 "State of Human Rights in 2013", op. cit., p. 156.

${ }^{99}$ Crisis Group telephone interviews, Maliha Zia, High Court advocate and gender and legal consultant, December 2014; Neelum Toru, KP PCSW chairperson, Peshawar, July 2014.

${ }^{100}$ Representation of the People (Amendment) Bill, 2014, introduced by Muttahida Qaumi Movement (MQM) National Assembly members Iqbal Qadri, Sufyan Yousuf, Nikhat Shakeel Khan and Sajid Ahmed on 8 April 2014.

${ }^{101}$ HRCP Secretary General I.A. Rehman, "Preparing for free and fair elections", Dawn, 15 September 2012; "Women, minority concerns to be addressed: Dar", The News, 26 September 2014. Crisis Group telephone interview, HRCP representative, Lower Dir, February 2015.

102 "ANP woman leader shot dead in Peshawar", The News, 17 August 2013.
} 
women they would be kidnapped and killed if they voted or otherwise participated in the "current democratic system [that] clashes with Sharia". ${ }^{103}$ But 44 per cent of eligible women did vote, underscoring commitment to democracy in a region where the state has yet to provide security or justice. ${ }^{104}$

\section{B. Access to Justice in FATA and KPK}

Constitutionally guaranteed gender equality and pro-women legislation does not extend to FATA, nor does the reach of courts and police. Disputes involving women, generally considered private, rarely go outside the extended family or community and are settled according to discriminatory tribal customs (rewaj). Trials are conducted by all-male jirgas, and a woman must be represented by a man. ${ }^{105}$ Jirgas have been known to treat women as commodities, including by ordering a woman relative of an accused male to be given in marriage to settle a feud, or a woman to be killed to preserve her male relatives' honour. ${ }^{106}$ "While jirgas do not compensate women [for crimes against them], it is customary for someone accused of murder to have to leave the village, give up property and give a sister in marriage to a relative of the deceased". ${ }^{107}$

Women have limited legal recourse. Under the FCR, the political agent (PA) has appellate power over the jirgas he appoints, but tasked with maintaining order rather than upholding rule of law - he has little incentive to oppose jirga decisions and protect women. ${ }^{108}$ Judicial oversight also is elusive. The 1997 FCR amendments empowered a commissioner appointed by KPK's governor to revise a PA decision and allowed a final appeal to a FATA tribunal composed of KPK's home, law and chief secretaries. Amendments in 2011 changed the tribunal's composition to two retired senior bureaucrats and a lawyer. ${ }^{109}$

A 2014 private member's bill sought to repeal Article 247 (7) of the constitution, which "by ousting the jurisdiction of the Supreme Court and of a High Court ... acts as a grave impediment in the way of the tribal people in securing their fundamental rights and thereby in their integration and mainstreaming". In support of the bill, the Senate in October 2014 unanimously adopted a resolution to extend the higher

\footnotetext{
103 "TTP urge voters to stay away from polls", The Express Tribune, 8 April 2013; "Taliban threat to women voters", Dawn, 22 August 2013.

${ }^{104}$ Crisis Group telephone interview, ECP official, Islamabad, 9 February 2015; "Election May 2013: detailed results of constituency PK42"; ““General elections (consolidated) PK42 (Hangu I) results: announced", ECP.

${ }^{105}$ Zakia Rubab Mohsin, "The Crisis of Internally Displaced Persons (IDPs) in the Federally Administered Tribal Areas of Pakistan and their Impact on Pashtun Women", Tigah: A Journal of Peace and Development, FATA Research Centre, vol. 3, July 2013, p. 98.

${ }^{106}$ Giving away women and girls to settle disputes is criminalised in the rest of the country under the Protection of Women law 2006. In 2012, the Supreme Court ruled that provinces must prevent jirgas from doing this. "The curse of swara", The Express Tribune, 18 September 2012; "Steps ordered against anti-women jirgas", ibid, 27 March 2012.

${ }^{107}$ Crisis Group interview, women's rights expert, FATA researcher, Islamabad, 5 December 2014.

${ }^{108}$ National police jurisdiction does not extend to FATA, which is policed by the paramilitary Frontier Corps, tribal levies (official tribal militias) and khassadars (tribal police). Levies and khassadars tasked with maintaining the peace are under the PA's authority.

${ }^{109}$ G.M. Chaudhry, "Summary of 2011 amendments to the Frontier Crimes Regulation", FATA Research Centre, 13 March 2013.
} 
judiciary's jurisdiction to FATA. ${ }^{110}$ The bill itself was unanimously approved by the Senate standing committee on law and justice on 20 February 2015, but pressure from the military, which resists extension of judicial and police jurisdiction over FATA, may delay a vote in the lower house of parliament. ${ }^{111}$

Military-devised deals with militants have also adversely affected women's security in KPK's PATA. In April 2009, as part of a peace deal with the Taliban-allied Tehreeke-Nifaz-e-Shariat-e-Mohammadi (TNSM), the KPKgovernment promulgated the Nizam-e-Adl Regulations 2009, imposing Sharia in the region. Government-appointed judicial officers trained in Islamic law now preside over qazi (religious) courts.

While protective legislation such as the Muslim Family Laws Ordinance no longer applies to PATA, the Hudood Ordinances still do. ${ }^{112}$ PATA's Islamic legislation might appear to have given women some rights denied by customary law, such as over inheritance, but in the absence of codified Islamic law, qazi courts that have little understanding of or sympathy for women's rights have broad interpretive powers. ${ }^{13}$ Judges and lawyers are unclear what laws now apply, and filing of cases is more complicated and expensive, further undermining women's ability to seek legal redress. ${ }^{114}$ Despite public opposition to Islamist militancy in Swat and neighbouring PATA districts, and the 2009 military operation against the TNSM, the PTI-JI government in Peshawar, like its predecessor, is unlikely to repeal the Nizam-e-Adl. There, as elsewhere, much also depends on whether the police are capable and willing to protect women.

During his tenure, a former KPK police inspector general said, the police established 65 women's complaint centres in police stations and hospitals, with support from the German development organisation GIZ. ${ }^{115}$ The KPK government has set up 105 women police desks in stations, in addition to "lady complaints units", staffed by policewomen in three model stations, with plans to expand them to all seven model stations to be created under a 2013-2017 UK-funded (Aitebaar) program. ${ }^{116}$ Currently, only 300 women officers (few senior) serve in the 70,000-strong force in a socially

\footnotetext{
${ }^{110}$ Constitution (Amendment) Act, 2014, draft bill by PPP Senator Farhatullah Babar. "Fundamental rights: civil society, lawyers demand superior courts in FATA", The Express Tribune, 28 January 2015; "House proceedings: Senate calls for extending court jurisdiction to FATA", ibid, 28 October 2014. The KPK assembly passed a similar unanimous resolution in 2012.

${ }^{111}$ The military, which has long used this strategic territory to promote perceived national security interests in Afghanistan, is averse to integrating FATA into the legal, judicial and constitutional mainstream. Crisis Group interviews, senators, Islamabad, November 2015. Crisis Group Report, Countering Militancy in FATA, op. cit. "Constitutional amendment: Senate body clears bill on tribal people's rights”, The Express Tribune, 20 February 2015.

${ }^{112}$ After the imposition of Sharia through the Nizam-e-Adl Regulation 2009, the Maintenance of Public Order (MPO) no longer applies to PATA.

${ }^{113}$ For detailed analysis, see Simi Kamal, "Nizam-e-Adl inside out”, NCSW, June 2010. "Litigation related to women under Nizam-e-Adl - Malakand division”, PCSW \& NCSW, 2014, p. 26.

114 "Litigation related to women under Nizam-e-Adl" op. cit., p. 27.

${ }^{115}$ Crisis Group interview, Ihsan Ghani, director general, NPB, Islamabad, 17 September 2014.

116 "Gender responsive policing in Khyber Pakhtunkhwa", www.kpolice.gov.kp. "Improving statecitizen relations in Pakistan; Special women's desk launched in Pakistani police stations", www.coffey.com (Coffey International is lead partner in a UK-funded program supporting peace and stability in conflict-affected areas, including better women's access to justice and police).
} 
conservative region where survivors of gender-based violence are unlikely to seek help from male officers. ${ }^{117}$

Women's upward mobility is constrained by politicised appointments and inability, due to family obligations or pressure, to attend mandatory and/or specialised training that requires distant travel for lengthy periods. ${ }^{118}$ Some women officers, the vast majority of whom are in lower ranks, may not even leave the station without male colleague approval. Policewomen are also often abuse victims. ${ }^{119}$ The KPK government must hold perpetrators accountable, end politicisation of appointments and ensure that policewomen have the authority and resources to do their jobs.

In 2013, the Peshawar High Court formed an exclusively female bench - the nation's first. ${ }^{120}$ "We have separate courts for acid attacks; we should have similar arrangements for rape and honour killing cases, and set up mobile courts to increase the justice system's proximity to women and its responsiveness to their needs", a civil judge said. ${ }^{121}$ Yet, there is only one female prosecutor in KPK's prosecution agencies. ${ }^{122}$ Penal reform should also be prioritised, not just in KPK but also countrywide. While the total of women prisoners is relatively low - some 1,000 in 2014, with 121 in KPK - there is a general lack of health services and high risk of abuse. ${ }^{123}$ In 2014, KPK authorities announced the intention to establish the province's first separate jail for women. ${ }^{124}$

Access to legal aid in KPK is gradually improving. The UNDP's Strengthening Rule of Law in Malakand (2011-2017) program has conducted legal aid clinics in which women were 45 per cent of the more than 8,000 attendees. UNDP has also established legal aid desks in Buner, Swat and Lower Dir districts that have received 188 cases, 70 per cent from women. ${ }^{125}$ The UK's Department for International Development (DFID) gives legal aid to women prisoners. ${ }^{126}$ Former Supreme Court Justice Nasir Aslam Zahid, who established a Karachi-based legal aid NGO for women prisoners in 2004, has, with retired Justice Arif Khilji, set up a legal advisory call centre that provides free legal advice to callers nationwide. ${ }^{127}$ In 2013, Madadgaar, a helpline headquartered in Karachi for "children and women suffering from violence, abuse and exploitation", set up provincial headquarters in Peshawar and other provincial capitals. ${ }^{128}$

\footnotetext{
${ }^{117}$ KPK police website, www.kpolice.gov.kp. Countrywide there are approximately 4,00o women, less than 1 per cent, in the total force of around 453,900. "Women policing: From isolation to integration", The Express Tribune, 3 February 2015.

118 "Equality in perspective - gender strategy of police 2012-2016", Gender Responsive Policing Project and NPB, Government of Pakistan, 2012.

${ }^{119}$ Crisis Group Report, Reforming Pakistan's Police, op. cit.

120 "Peshawar High Court makes history”, The Express Tribune, 6 May 2013.

${ }^{121}$ Judge Shazia Munawar Makhdoom, conference address, "Combating violence, ending impunity”, NCSW seminar, Islamabad, 16 December 2014.

122 "Leading the way: first female prosecutor in Khyber Pakhtunkhwa fights for women's rights", UK Department for International Development (DFID), 28 November 2014.

123 "State of Human Rights in 2013", op. cit., p. 62; "Female prisoners lack health care: report", The News, 17 July 2014; "Females behind bars: situation and needs assessment in female prisons and barracks", UN Office of Drugs and Crime (UNODC), 2011.

124 “KP to set up Pakistan's first high security prison”, Dawn, 6 May 2014.

125 UNDP Pakistan website, www.pk.undp.org.

126 “Aitebaar E. Bulletin”, January 2015.

127 "Footprints: dialling for justice”, Dawn, 30 January 2015.

${ }^{128}$ Madadgaar website, www.madadgaar.org.
} 
Social and cultural constraints may, however, prevent many women from accessing free legal advice, possibly a reason why some activists, such as Khwendo Jirga founder Tabassum Adnan, try to use more familiar local structures such as jirga's, but restructured to address women's needs. ${ }^{129}$ In January 2014, Adnan was invited to a regular jirga to help feuding families reach an alternative solution after she stopped a girl from being given away in swara. "We called our group a jirga so we would be taken seriously and accepted in men's jirgas", she said. ${ }^{130}$ KPK's PCSW is piloting a women's jirga as a referral system and alternate dispute-resolution mechanism. ${ }^{131}$

Such well-meaning initiatives, though, may prove counterproductive, by legitimising and reinforcing a parallel informal justice system responsible for perpetuating gender inequality. The women's rights organisation Shirkat Gah, which has run "women friendly spaces" since 2011, including in Swat district, has a different approach. Instead of working with informal justice mechanisms, it intends to engage with state institutions such as the police to address gender-based violence, thus strengthening the link between the citizen and the state and contributing to community reconstruction and rehabilitation in conflict zones. ${ }^{132}$

129 “Pakistan's women only jirga fights for equal rights", Newsweek, 11 July 2013.

${ }^{130}$ Crisis Group interview, Islamabad, 11 December 2014. Khwendo Jirga or Sisters' Council, based

in Swat's Mingora district, gives women in need guidance and mediates disputes.

${ }^{131}$ Crisis Group interview, Neelum Toru, chair, KPK PCSW, Islamabad, 16 December 2014.

${ }^{132}$ Crisis Group interview, Shirkat Gah representative, Lahore, 12 February 2015. 


\section{Women and Armed Conflict}

\section{A. Life in Conflict Zones}

Women have been badly hit by both militancy and heavy-handed military operations that have disrupted the peace, displaced communities and destroyed homes and livelihoods in FATA's and KPK's conflict zones. KPK's Swat district is an example. Until dislodged by the 2009 offensive, the TNSM barred women from working and girls from attending schools and, on occasion, publicly flogged those who did not comply with its version of Sharia. On 9 October 2012, three years after the military claimed to have cleared Swat of militant groups, girl education activist Malala Yousafzai and two schoolmates survived an attack in the district's largest city, Mingora. Still today, despite the military's continued presence, standing up for women's rights means risking one's life.

The state's reliance on informal militias (lashkars) - renamed "peace committees" to avoid association with those run by militant outfits - also undermines the rule of law and human rights in PATA and FATA. Many are little more than criminal gangs, responsible for countless abuses, including killings, abductions and forced marriages. ${ }^{133}$ The head of an NGO that has researched the impact of conflict on women in Swat said, "women are just too afraid to talk", unsurprising when the perpetrators have state sanction. ${ }^{134}$ Attacks on women officials and NGO personnel including teachers and health workers - happen regularly. On 5 July 2012, for example, Farida Afridi, co-founder of an NGO working to promote women's rights in FATA, was shot dead. ${ }^{135}$

There is considerable physical, financial and emotional cost for women living in or fleeing conflict-affected regions. Conflict for many women means the loss of a father, husband or son who has joined the militants, died in combat or "disappeared"kidnapped for ransom or held in a military-run internment centre. ${ }^{136}$ With already scarce livelihoods worsening because of military operations or militant violence, many men have also left to work within the country or abroad, mainly the Middle East. The woman left behind is dependent on the extended family, but without a husband or a son to represent her, her needs, including healthcare and other necessities, are often neglected. Moreover, "it is not uncommon for women in these situations to be sexually abused by male in-laws". ${ }^{137}$

Within FATA's conflict zones, sexual violence is endemic, but, a donor representative said, "talking about sexual violence is taboo". ${ }^{138}$ In 2011, Khwendo Kor, which has extensive experience working in FATA and KPK on female rights, published ac-

\footnotetext{
${ }^{133}$ Crisis Group Report, Countering Militancy in PATA, op. cit.

${ }^{134}$ Crisis Group interview, Islamabad, November 2014.

135 "Farida Afridi”, The Express Tribune, 7 July 2012.

${ }^{136}$ Mohsin, op. cit., p. 101; "Pakistan: Swat women fear to tread", IRIN News, 13 September 2013. Hundreds of militant suspects are held in military-run internment centres in KPK and FATA. "Chamber of horrors: Govt lifts lid on secret K-P internment centres", The Express Tribune, 10 July 2013; "700 missing persons shifted to internment centres", Dawn, 11 December 2013.

${ }^{137}$ Crisis Group interview, civil society activist and informed observer from Swat, Islamabad, December 2014. Nazish Brohi and Dr Saba Gul Khattak, "Exploring women's voices - women in conflict zones: the Pakistan study - community conversations in Balochistan and Swat", Women's Regional Network, 2013, p. 34.

${ }^{138}$ Crisis Group interview, donor representative, Islamabad, November 2014.
} 
counts by displaced women from FATA of sexual and other physical violence by militants and security officials. ${ }^{139}$ Armed conflict has contributed to men abusing or murdering women relatives with impunity. "When a woman is killed, you can just blame it on the Taliban or the paramilitary depending on what side you're on", said a women's rights activist and FATA researcher. ${ }^{140}$

Militant violence and heavy-handed military operations have also undermined access to health care and education. There are anecdotal accounts of miscarriages and deliveries while fleeing armed conflict and of stress impacting lactation. ${ }^{141}$ Schools have been destroyed and teachers intimidated by extremists. ${ }^{142}$ Persistent insecurity and militant threats, particularly to women teachers and girls, have made parents reluctant to let daughters attend school. ${ }^{143}$

Internally displaced persons (IDPs) by conflict are particularly vulnerable. ${ }^{144} \mathrm{Ex}-$ ploiting the physical and financial vulnerabilities of displaced families, criminal gangs traffic women, forcing them into prostitution. ${ }^{145}$ The extent is difficult to ascertain due to the absence of a formal law enforcement sector and the social acceptability of the sale or exchange of women by some communities. ${ }^{146}$ Relief to IDPs is also gender insensitive. There are almost two million IDPs from the worst-hit FATA agencies (North and South Waziristan and Khyber). More than 74 per cent of the nearly one million displaced in the ongoing military operation in North Waziristan are women and dependent children. ${ }^{147}$ Women IDPs find it particularly difficult to obtain assistance, including food and health care. There are few women nurses and doctors and insufficient women relief workers; and aid distribution points are often in public spaces most women find difficult to access. Those in IDP camps even have limited access to toilets. ${ }^{148}$

The military and civil bureaucracies restrict local and international NGOs' access to FATA's and PATA's IDP-hosting areas, though they could fill gaps in the state's help for displaced females. "A senior-ranking army officer said they have disallowed

\footnotetext{
139 "Horrors of sexual abuse in conflict-stricken FATA", The Express Tribune, 15 December 2011; "Pakistani families forced to flee FATA 'paradise”, IRIN News, 10 June 2013. Khwendo Kor is a Peshawar-based NGO working in FATA and KPK on women's and girls' rights.

${ }^{140}$ Crisis Group interview, Islamabad, November 2014.

${ }^{141}$ Crisis Group interviews, NGO workers, Bannu, Peshawar and Islamabad, July, November 2014. Many fleeing the ongoing North Waziristan operation take refuge in KPK's Bannu district.

${ }^{142}$ According to the data in the 15 May 2014 report of the UN Secretary-General to the Security Council (A/68/878/S/2104/339), of the 78 militant attacks in 2013 reported to the UN, 51 were in KPK and nineteen in FATA, including five female teachers and two health workers killed in KPK in January; on 26 March, a female teacher was executed in Khyber agency; and on 5 September, thirteen female students were injured in a bomb blast in KPK's Bannu district.

${ }^{143}$ Crisis Group Report, Education Reform in Pakistan, op. cit.

${ }^{144}$ See Crisis Group Reports, No End to Humanitarian Crises; Aid and Conflict in Pakistan; and Briefings, The Worsening IDP Crisis; and IDP Crisis, all op. cit.

145 Crisis Group interviews, rights activists, Peshawar, July-November 2014.

${ }^{146}$ Mohsin, op. cit., p. 108.

147 "IDPs to start going home to North Waziristan this Sunday: Qadir Baloch: Offensive in North Waziristan began in June 2014 and displaced nearly a million people”, Reuters, 13 March 2015; "PRCS IDPs NWA Operation", ReliefWeb, Situation Report, no. 9, 21 July 2014.

${ }^{148}$ Crisis Group interviews, NGO workers, Bannu, July 2014; telephone interview Zohra Yusuf, chair, HRCP, Karachi, 14 February 2015. Also, Sarah Chatellier, Shabana Fayyaz, "Women's Role in Post-Conflict Reconstruction and Rehabilitation in Pakistan", The Institute for Inclusive Security, August 2012, pp. 2-4.
} 
NGOs because you don't know who comes in the garb of NGOs". ${ }^{149}$ Claiming there are no IDPs, only persons who will soon go home, the government created a Temporary Dislocated Persons (TDP) Support and Management Secretariat in July 2014. Headed by a general, tasked with overseeing response to North Waziristan's IDPs and bypassing civilian disaster management entities, it has further increased military control of relief, which is being used as a counter-insurgency tool. Along with lifting all restrictions on local and international NGOs in IDP areas, the government should investigate allegations of discriminatory assistance to ensure that women have unimpeded access. Aid to female heads of household, who are the most disadvantaged, should be prioritised..$^{150}$ The international community, particularly the UN and donor countries, should ensure that women's needs are adequately assessed in relief and rehabilitation assistance to conflict-affected and internally displaced persons.

\section{B. Women, Peace and Security}

The lack of transparency in relief aid for IDPs is just one aspect of the military's opaque counter-insurgency/counter-terrorism policy, which has swung since 2004 between peace deals with violent extremists in FATA and PATA and indiscriminate force. ${ }^{151}$ Women, though among the main targets of militants' efforts to impose ultraorthodox Islam, have been consistently excluded from military-led negotiations. Gender perspective is largely absent from state strategies to counter violent extremism more generally. The ANP vice president in KPK, Bushra Gohar, said, "anyone who takes up arms is considered a stakeholder [by the state]. There needs to be a paradigm shift where we recognise that the primary stakeholders are those most affected by the conflict". ${ }^{152}$ According to a Peshawar-based rights' activist, "the move not to include women is intentional. It's not because women have nothing to bring to the table or because they are not party to the conflict, but because they will bring questions to the table that will make all other stakeholders uncomfortable, such as rights violations". ${ }^{153}$

Pakistan has yet to go beyond endorsing UN Security Council Resolution 1325 (2000), which reaffirmed "the importance of women in the prevention and resolution of conflicts and in peacebuilding" and stressed "the importance of their equal participation and full involvement in all efforts for the maintenance of peace and security, and the need to increase their role in decision-making with regard to conflict prevention and resolution". The rationale, said a prominent women's right advocate, is that it is merely in a law and order crisis, not armed conflict. ${ }^{154}$ Yet, Pakistan has ratified the CEDAW, which with the Beijing Declaration provides a framework for women's role in peace and security initiatives, legally binding states to ensure their

\footnotetext{
${ }^{149}$ Crisis Group interview, Bannu-based NGO representative, Bannu, July 2014.

${ }^{150}$ Crisis Group interview, humanitarian aid worker, Islamabad, 2 December 2014.

${ }^{151}$ For details, see Crisis Group Reports, The Militant Jihadi Challenge; Countering Militancy in FATA; and Countering Militancy in PATA, both op. cit.

${ }^{152}$ Crisis Group interview, Islamabad, 1 December 2014. Gohar is also a human rights activist.

${ }^{153}$ Crisis Group telephone interview, Khadim Hussain, managing director, Baacha Khan Trust Education Foundation, 27 November 2014. The foundation is a non-profit working to promote peace, democracy, human rights and development in Pakistan and Afghanistan.

${ }^{154}$ Crisis Group interview, Farida Shaheed, executive director, Shirkat Gah, Lahore, 12 February 2015. Sehar Tariq, "Gender sensitisation for conflict management and resolution", Jinnah Institute (an Islamabad-based think-tank), March 2011.
} 
"equal access to, and equal opportunities in, political and public life". The Beijing Platform of Action calls for "increas[ing] the participation of women in conflict resolution at decision-making levels and protect[ing] women living in situations of armed and other conflicts". ${ }^{155}$ States must report on implementation of national action plans in their CEDAW reports. ${ }^{156}$

Pakistan's 1998 National Action Plan for Women identified the need to change the "status of tribal areas" and "to introduce and implement just laws", so as to "protect the rights of women during sectarian, ethnic and political conflicts within the country". ${ }^{157}$ The consultations of the PPP-led federal government (2008-2013) with civil society groups on revisions ended when the eighteenth constitutional amendment devolved the powers and mandate of the federal women's affairs ministry to the provinces, which have yet to follow up.

The multi-donor-funded 2010 Post-Conflict Needs Assessment (PCNA) for FATA and KPK, outlining a ten-year peacebuilding strategy, identified women's marginalisation as "critical" in understanding the "drivers of the crisis". Calling for a rightsbased, inclusive approach to building and sustaining peace, it emphasised: "If only half the population enjoys basic freedoms and rights, conflict will endure". ${ }^{158}$ Yet, meaningful reform remains absent, and the World Bank-administered Multi-Donor Trust Fund (MDTF), tasked with funding the strategy, has struggled to mainstream gender in its activities. ${ }^{159}$ The international community, particularly the UN and donor countries, should continue to enhance support for developing gender-responsive policing and also ensure that women's needs, rights and priorities are meaningfully addressed in all aid programing.

Some local civil society efforts are being made. Amn-o-Nisa, a network of professional women founded in 2011, tries to promote tolerance and counter radicalisation. ${ }^{160}$ Since end-2008, its founding organisation, PAIMAN Alumni Trust, has set up women and youth groups in KPK and all FATA agencies except North Waziristan to mediate property and family-feud disputes lest they escalate into conflict. ${ }^{161}$ The groups also aim to counter radicalisation within their communities by identifying and engaging young people attracted to violent extremism. ${ }^{162}$ Nationally, however, women's rights activists have yet to mobilise a collective or coordinated movement, comparable

\footnotetext{
155 "Platform for Action for Equality, Development and Peace", UN Fourth World Conference on Women, Beijing, September 1995.

156 "Women, peace and security - CEDAW and Security Council Resolution 1325: a quick guide", UN Development Fund for Women, 2006, p. 8.

157 "National Plan of Action", women development ministry, Government of Pakistan, September 1998, p. 39.

158 "Post-Crisis Needs Assessment: Khyber-Pakhtunkhwa and Federally Administered Tribal Areas", FATA Secretariat, Asian Development Bank, European Union, UN and World Bank, September 2010. ${ }^{159}$ Crisis Group interviews, donor representatives, Islamabad, November 2014. DFID's Aitebaar program aims to provide peacekeeping support to the PCNA.

${ }^{160}$ Crisis Group interviews, Mossarat Qadeem, executive director, PAIMAN Alumni Trust, Islamabad, 8 January 2015; Huma Chugtai, gender and legal expert, Islamabad, 11 December 2014.

${ }^{161}$ It established the coalition with support from the U.S.-based Institute for Inclusive Security and USIP. Sarah Chatellier, "Pakistani women moderating extremism: a coalition-building case study", Institute for Inclusive Security, August 2012.

${ }^{162}$ Crisis Group interview, Mossarat Qadeem, Islamabad, 8 January 2015.
} 
to earlier campaigns against discriminatory laws, to monitor rights violations in conflict zones and to demand a voice in counter-insurgency/counter-terrorism policy. ${ }^{163}$

The Colombo-based South Asians for Human Rights (SAHR), with members from Afghanistan, India, Bhutan, Maldives, Bangladesh, Nepal and Sri Lanka, as well as Pakistan, intends to form peace missions to meet with stakeholders in conflictaffected areas. ${ }^{164}$ "We want to develop a women's regional peace agenda so that we can engage in informed advocacy", said a senior jurist, women's rights advocate and SAHR chairperson. ${ }^{165}$ A regional civil society coalition formed in 2011, the Women's Regional Network, joins female leaders and rights activists from Pakistan, Afghanistan and India to strengthen women's security and promote participation in preventing and resolving conflict. ${ }^{166}$ "Women must be brought in not because they're women, but because they have the relevant expertise", said Asma Jahangir, the former UN Special Rapporteur on extrajudicial, summary or arbitrary executions. ${ }^{167}$

\footnotetext{
${ }^{163}$ Crisis Group interviews, NGO workers, rights activists and lawyers, Islamabad and Lahore, November 2014-February 2015. "We had a focused strategy against the Islamisation of the law; now we're overwhelmed by the rights violations that are going on. It's one horror after another". Crisis Group telephone interview, HRCP chair and WAF founding member Zohra Yusuf, 14 February 2015. ${ }^{164}$ SAHR, www.southasianrights.org, was set up in 2010.

${ }^{165}$ Crisis Group interview, Hina Jilani, Lahore, 12 February 2015.

${ }^{166}$ Crisis Group interviews, Kishwar Sultana, director, Insan Foundation, Islamabad, 25 November, and Bushra Gohar, ANP vice president in KPK, Islamabad, 1 December 2014.

${ }^{167}$ Crisis Group interview, Lahore, 13 February 2015.
} 


\section{Conclusion}

In 2015 - the Beijing Fourth World Conference's twentieth and UN Security Council Resolution 1325's fifteenth anniversary - there is little to show that Pakistan is meeting commitments such as those in its 2011 CEDAW report that "efforts are underway to ... promote gender equality, curb violence against women and enact legislation to empower Pakistani women". ${ }^{168}$ This implementation failure undermines political, economic and social development - all necessary to consolidate Pakistan's still fragile democracy. As security challenges grow, in the conflict zones in particular, silencing women makes peace and stability more elusive.

Despite enhanced political participation of women and the passage of a number of helpful laws since the democratic transition began in 2008, much remains to be done. Nationwide, discriminatory legislation denies women constitutionally guaranteed equality and protections. Pakistan should repeal all such laws, including the Hudood Ordinances, to end the state-sanctioned gender discrimination that has undermined women's rights and security and fostered violence and intolerance. There is also dire need to repeal the FCR and extend constitutionally guaranteed freedoms to women in FATA, whose lives and livelihoods are gravely threatened by militant violence and disrupted by indiscriminate military operations. Since the eighteenth constitutional amendment has placed the onus on KPK and the other provinces to end legally enshrined gender-based discrimination, their governments should act to protect and advance women's rights.

The federal and provincial governments must ensure that women have access to a gender-responsive police and an accessible, impartial judiciary in order to mitigate the impact of violence and armed conflict. Women and women's rights activists are determined, despite barriers and threats, to continue their struggle for political and economic empowerment. The government must hear their voices and incorporate them into policymaking, including counter-insurgency, which can only succeed when those most affected are at the heart of peacebuilding.

Islamabad/Brussels, 8 April 2015

\footnotetext{
168 "CEDAW: Consideration of reports submitted by States parties under article 18 of the Convention on the Elimination of All Forms of Discrimination against Women: Fourth periodic reports of States parties. Pakistan”, 24 September 2011.
} 


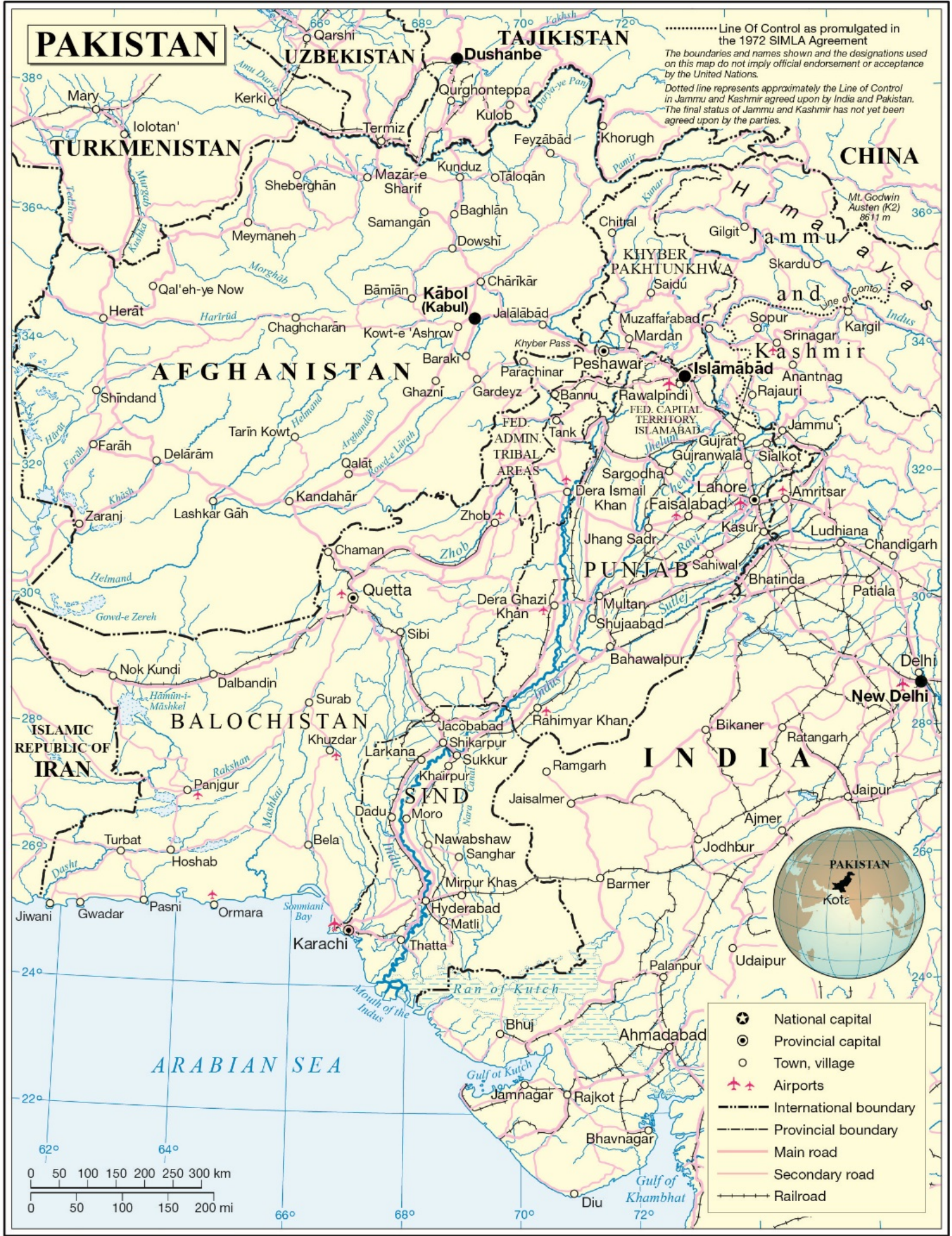




\section{Appendix B: Glossary}

ANP - Awami National Party, a secular Pashtundominated party, headed a coalition government in KPK with the PPP, 2008-2013.

ECP - Election Commission of Pakistan, constitutionally mandated to hold elections to national, provincial and local legislatures, prepare electoral rolls for elections to the National Assembly, the lower house of parliament, and the four provincial assemblies and conduct indirect elections to the Senate, the upper house of parliament.

FATA - Federally Administered Tribal Areas, comprising seven administrative districts, or agencies, and six Frontier Regions bordering on south-eastern Afghanistan

FCR - Frontier Crimes Regulations, a draconian, colonial-era legal framework adopted in 1901 and retained after independence to govern FATA.

HRCP - The independent Human Rights Commission of Pakistan.

Hudood Ordinances - Passed by Zia-ul-Haq's military regime on 16 February 1979 and still in force, prescribing punishments in accordance with orthodox Islamic law, including amputation of limbs, flogging, stoning and other forms of the death penalty for crimes ranging from theft, adultery and extramarital sexual intercourse (called fornication) to consumption of liquor.

JI - Jamaat-Islami, currently a coalition partner in the KPK government.

KPK - Khyber Pakhtunkhwa, formerly known as the Northwest Frontier Province (NWFP).

NCSW - National Commission on the Status of Women, established by ordinance in 2000 under the women development ministry; in 2012, the National Commission on the Status of Women law strengthened its powers and autonomy.

PATA - Provincially Administered Tribal Areas, which, along with two of its biggest districts, Chitral and Swat, includes Upper Dir, Lower Dir, Malakand, Shangla, parts of Kohistan district, the tribal area adjoining Mansehra district and the former state of Amb.

PCSW - Provincial Commission on the Status of Women, established by provincial assemblies.

PML-N - Pakistan Muslim League-Nawaz, led by Prime Minister Nawaz Sharif, currently heading a majority government at the centre and in Punjab.
PPP - Pakistan Peoples Party, founded by Zulfikar Ali Bhutto in 1967. Since Benazir Bhutto's December 2007 assassination, it is headed by her widower, former President Asif Ali Zardari, and son, Bilawal Bhutto Zardari. It led the coalition government in the centre, 2008-2013, and is currently the largest opposition party in the National Assembly. It also heads the Sindh provincial government.

PTI - Pakistan Tehreek-e-Insaf, founded by Imran Khan, currently heading the coalition government in Khyber Pakhtunkhwa with Jl.

Qanun-e-Shahadat - The Evidence Act, as amended by General Zia-ul-Haq's regime in 1984.

Qazi court - Sharia (Islamic law) court.

Qisas and Diyat - Retribution and monetary compensation, elements of Sharia (Islamic law) on murder. 


\section{Appendix C: About the International Crisis Group}

The International Crisis Group (Crisis Group) is an independent, non-profit, non-governmental organisation, with some 125 staff members on five continents, working through field-based analysis and high-level advocacy to prevent and resolve deadly conflict.

Crisis Group's approach is grounded in field research. Teams of political analysts are located within or close by countries at risk of outbreak, escalation or recurrence of violent conflict. Based on information and assessments from the field, it produces analytical reports containing practical recommendations targeted at key international decision-takers. Crisis Group also publishes CrisisWatch, a twelve-page monthly bulletin, providing a succinct regular update on the state of play in all the most significant situations of conflict or potential conflict around the world.

Crisis Group's reports and briefing papers are distributed widely by email and made available simultaneously on the website, www.crisisgroup.org. Crisis Group works closely with governments and those who influence them, including the media, to highlight its crisis analyses and to generate support for its policy prescriptions.

The Crisis Group Board of Trustees - which includes prominent figures from the fields of politics, diplomacy, business and the media - is directly involved in helping to bring the reports and recommendations to the attention of senior policy-makers around the world. Crisis Group is co-chaired by former UN Deputy Secretary-General and Administrator of the United Nations Development Programme (UNDP), Lord Mark Malloch-Brown, and Dean of Paris School of International Affairs (Sciences Po), Ghassan Salamé.

Crisis Group's President \& CEO, Jean-Marie Guéhenno, assumed his role on 1 September 2014. Mr. Guéhenno served as the United Nations Under-Secretary-General for Peacekeeping Operations from 2000-2008, and in 2012, as Deputy Joint Special Envoy of the United Nations and the League of Arab States on Syria. He left his post as Deputy Joint Special Envoy to chair the commission that prepared the white paper on French defence and national security in 2013.

Crisis Group's international headquarters is in Brussels, and the organisation has offices or representation in 26 locations: Baghdad/Suleimaniya, Bangkok, Beijing, Beirut, Bishkek, Bogotá, Cairo, Dakar, Dubai, Gaza City, Islamabad, Istanbul, Jerusalem, Johannesburg, Kabul, London, Mexico City, Moscow, Nairobi, New York, Seoul, Toronto, Tripoli, Tunis, Washington DC. Crisis Group currently covers some 70 areas of actual or potential conflict across four continents. In Africa, this includes, Burkina Faso, Burundi, Cameroon, Central African Republic, Chad, Côte d'Ivoire, Democratic Republic of the Congo, Eritrea, Ethiopia, Guinea, Guinea-Bissau, Kenya, Liberia, Madagascar, Nigeria, Sierra Leone, Somalia, South Sudan, Sudan, Uganda and Zimbabwe; in Asia, Afghanistan, Indonesia, Kashmir, Kazakhstan, Kyrgyzstan, Malaysia, Myanmar, Nepal, North Korea, Pakistan, Philippines, Sri Lanka, Taiwan Strait, Tajikistan, Thailand, Timor-Leste, Turkmenistan and Uzbekistan; in Europe, Armenia, Azerbaijan, Bosnia and Herzegovina, Cyprus, Georgia, Kosovo, Macedonia, North Caucasus, Serbia and Turkey; in the Middle East and North Africa, Algeria, Bahrain, Egypt, Iran, Iraq, Israel-Palestine, Jordan, Lebanon, Libya, Morocco, Syria, Tunisia, Western Sahara and Yemen; and in Latin America and the Caribbean, Colombia, Guatemala, Mexico and Venezuela.

This year Crisis Group receives financial support from a wide range of governments, foundations, and private sources. Crisis Group holds relationships with the following governmental departments and agencies: Australian Department of Foreign Affairs and Trade, Austrian Development Agency, Belgian Ministry of Foreign Affairs, Canadian Department of Foreign Affairs, Trade and Development, Danish Ministry of Foreign Affairs,, Dutch Ministry of Foreign Affairs, European Union Instrument for Stability, Finnish Foreign Ministry, French Ministry of Foreign Affairs, Irish Aid, Italian Foreign Ministry, Principality of Liechtenstein, Luxembourg Ministry of Foreign Affairs, New Zealand Ministry of Foreign Affairs and Trade, Norwegian Ministry of Foreign Affairs, Swedish Ministry of Foreign Affairs, Swiss Federal Department of Foreign Affairs, Turkish Ministry of Foreign Affairs, United Kingdom Department for International Development, U.S. Agency for International Development.

Crisis Group also holds relationships with the following foundations: Adessium Foundation, Carnegie Corporation of New York, Henry Luce Foundation, John D. and Catherine T. MacArthur Foundation, Koerber Foundation, Oak Foundation, Open Society Foundations, Open Society Initiative for West Africa, Ploughshares Fund, Rockefeller Brothers Fund, and Tinker Foundation. 


\section{Appendix D: Reports and Briefings on Asia since 2012}

As of 1 October 2013, Central Asia publications are listed under the Europe and Central Asia program.

\section{North East Asia}

Stirring up the South China Sea (I), Asia Report $\mathrm{N}^{\circ} 223,23$ April 2012 (also available in Chinese).

Stirring up the South China Sea (II): Regional Responses, Asia Report №229, 24 July 2012 (also available in Chinese).

North Korean Succession and the Risks of Instability, Asia Report №230, 25 July 2012 (also available in Chinese and Korean).

China's Central Asia Problem, Asia Report $\mathrm{N}^{\circ} 244,27$ February 2013 (also available in Chinese).

Dangerous Waters: China-Japan Relations on the Rocks, Asia Report N²45, 8 April 2013 (also available in Chinese).

Fire on the City Gate: Why China Keeps North Korea Close, Asia Report N²54, 9 December 2013 (also available in Chinese).

Old Scores and New Grudges: Evolving SinoJapanese Tensions, Asia Report №258, 24 July 2014 (also available in Chinese).

Risks of Intelligence Pathologies in South Korea, Asia Report N²59, 5 August 2014.

\section{South Asia}

Sri Lanka's North (I): The Denial of Minority Rights, Asia Report N²19, 16 March 2012.

Sri Lanka's North (II): Rebuilding under the Military, Asia Report N²20, 16 March 2012.

Talking About Talks: Toward a Political Settlement in Afghanistan, Asia Report №221, 26 March 2012.

Pakistan's Relations with India: Beyond Kashmir?, Asia Report N²24, 3 May 2012.

Bangladesh: Back to the Future, Asia Report №226, 13 June 2012.

Aid and Conflict in Pakistan, Asia Report №227, 27 June 2012.

Election Reform in Pakistan, Asia Briefing N`137, 16 August 2012.

Nepal's Constitution (I): Evolution Not Revolution, Asia Report №233, 27 August 2012 (also available in Nepali).

Nepal's Constitution (II): The Expanding Political Matrix, Asia Report №234, 27 August 2012 (also available in Nepali).

Afghanistan: The Long, Hard Road to the 2014 Transition, Asia Report N²36, 8 October 2012.

Pakistan: No End To Humanitarian Crises, Asia Report N²37, 9 October 2012.
Sri Lanka: Tamil Politics and the Quest for a Political Solution, Asia Report N ${ }^{\circ} 239,20$ November 2012.

Pakistan: Countering Militancy in PATA, Asia Report N²42, 15 January 2013.

Sri Lanka's Authoritarian Turn: The Need for International Action, Asia Report N²43, 20 February 2013.

Drones: Myths and Reality in Pakistan, Asia Report №247, 21 May 2013.

Afghanistan's Parties in Transition, Asia Briefing №141, 26 June 2013.

Parliament's Role in Pakistan's Democratic Transition, Asia Report N $² 49,18$ September 2013.

Women and Conflict in Afghanistan, Asia Report №252, 14 October 2013.

Sri Lanka's Potemkin Peace: Democracy under Fire, Asia Report N²53, 13 November 2013.

Policing Urban Violence in Pakistan, Asia Report №255, 23 January 2014.

Afghanistan's Insurgency after the Transition, Asia Report N256, 12 May 2014.

Education Reform in Pakistan, Asia Report №257, 23 June 2014.

Afghanistan's Political Transition, Asia Report №260, 16 October 2014.

Resetting Pakistan's Relations with Afghanistan, Asia Report N²62, 28 October 2014.

Sri Lanka's Presidential Election: Risks and Opportunities, Asia Briefing $N^{\circ} 145$, 9 December 2014.

Mapping Bangladesh's Political Crisis, Asia Report N²64, 9 February 2015.

\section{South East Asia}

Indonesia: From Vigilantism to Terrorism in Cirebon, Asia Briefing $N^{\circ} 132,26$ January 2012.

Indonesia: Cautious Calm in Ambon, Asia Briefing N¹33, 13 February 2012.

Indonesia: The Deadly Cost of Poor Policing, Asia Report №218, 16 February 2012 (also available in Indonesian).

Timor-Leste's Elections: Leaving Behind a Violent Past?, Asia Briefing N¹34, 21 February 2012.

Indonesia: Averting Election Violence in Aceh, Asia Briefing Nº135, 29 February 2012.

Reform in Myanmar: One Year On, Asia Briefing №136, 11 April 2012 (also available in Burmese and Chinese).

The Philippines: Local Politics in the Sulu Archipelago and the Peace Process, Asia Report №225, 15 May 2012. 
How Indonesian Extremists Regroup, Asia Report $N^{\circ} 228,16$ July 2012 (also available in Indonesian).

Myanmar: The Politics of Economic Reform, Asia Report №231, 27 July 2012 (also available in Burmese and Chinese).

Indonesia: Dynamics of Violence in Papua, Asia Report N²32, 9 August 2012 (also available in Indonesian).

Indonesia: Defying the State, Asia Briefing N¹38, 30 August 2012.

Malaysia's Coming Election: Beyond Communalism?, Asia Report №235, 1 October 2012.

Myanmar: Storm Clouds on the Horizon, Asia Report N²38, 12 November 2012 (also available in Chinese and Burmese).

The Philippines: Breakthrough in Mindanao, Asia Report №240, 5 December 2012.

Thailand: The Evolving Conflict in the South, Asia Report N²41, 11 December 2012.

Indonesia: Tensions Over Aceh's Flag, Asia Briefing $\mathrm{N}^{\circ} 139,7$ May 2013.

Timor-Leste: Stability At What Cost?, Asia Report N²46, 8 May 2013.

A Tentative Peace in Myanmar's Kachin Conflict, Asia Briefing $\mathrm{N}^{\circ}$ 140, 12 June 2013 (also available in Burmese and Chinese)

The Philippines: Dismantling Rebel Groups, Asia Report N²48, 19 June 2013.

The Dark Side of Transition: Violence Against Muslims in Myanmar, Asia Report N²51, 1 October 2013 (also available in Burmese and Chinese).

Not a Rubber Stamp: Myanmar's Legislature in a Time of Transition, Asia Briefing N²142, 13 December 2013 (also available in Burmese and Chinese).

Myanmar's Military: Back to the Barracks?, Asia Briefing $N^{\circ} 143,22$ April 2014 (also available in Burmese).

Counting the Costs: Myanmar's Problematic Census, Asia Briefing N¹44, 15 May 2014 (also available in Burmese).

Myanmar: The Politics of Rakhine State, Asia Report N²61, 22 October 2014 (also available in Burmese).

A Coup Ordained? Thailand's Prospects for Stability, Asia Report N²63, 3 December 2014. 


\section{Appendix E: International Crisis Group Board of Trustees}

\section{PRESIDENT \& CEO \\ Jean-Marie Guéhenno \\ Former UN Under-Secretary-General \\ for Peacekeeping Operations}

\section{CO-CHAIRS}

Lord (Mark) Malloch-Brown

Former UN Deputy Secretary-General and Administrator of the United Nations Development Programme (UNDP)

Ghassan Salamé

Dean, Paris School of International Affairs, Sciences Po

\section{VICE-CHAIR}

\section{Ayo Obe}

Legal Practitioner, Columnist and

TV Presenter, Nigeria

\section{OTHER TRUSTEES}

Morton Abramowitz

Former U.S. Assistant Secretary of

State and Ambassador to Turkey

Hushang Ansary

Chairman, Parman Capital Group LLC

Nahum Barnea

Political Columnist, Israel

\section{Samuel Berger}

Chair, Albright Stonebridge Group

LLC; Former U.S. National Security Adviser

\section{Carl Bildt}

Former Foreign Minister of Sweden

\section{Emma Bonino}

Former Foreign Minister of Italy and Vice-President of the Senate;

Former European Commissioner for Humanitarian Aid

Micheline Calmy-Rey

Former President of the Swiss Confederation and Foreign Affairs Minister

\section{Cheryl Carolus}

Former South African High

Commissioner to the UK and

Secretary General of the African National Congress (ANC)

\section{Maria Livanos Cattau}

Former Secretary-General of the International Chamber of Commerce

\section{Wesley Clark}

Former NATO Supreme Allied

Commander

\section{Sheila Coronel}

Toni Stabile Professor of Practice in Investigative Journalism; Director, Toni Stabile Center for Investigative Journalism, Columbia University, U.S.

\section{Mark Eyskens}

Former Prime Minister of Belgium

\section{Lykke Friis}

Prorector For Education at the University of Copenhagen. Former Climate \& Energy Minister and Minister of Gender Equality of Denmark

\section{Frank Giustra}

President \& CEO, Fiore Financial Corporation

\section{Mo Ibrahim}

Founder and Chair, Mo Ibrahim Foundation; Founder, Celtel International

\section{Wolfgang Ischinger}

Chairman, Munich Security

Conference; Former German Deputy

Foreign Minister and Ambassador to the UK and U.S.

\section{Asma Jahangir}

Former President of the Supreme Court Bar Association of Pakistan; Former UN Special Rapporteur on the Freedom of Religion or Belief

\section{Yoriko Kawaguchi}

Former Minister for Foreign Affairs, Japan

\section{Wadah Khanfar}

Co-Founder, Al Sharq Forum; Former Director General, Al Jazeera Network

\section{Wim Kok}

Former Prime Minister of the

Netherlands

\section{Ricardo Lagos}

Former President of Chile

Joanne Leedom-Ackerman

Former International Secretary of PEN International; Novelist and journalist, U.S.

Sankie Mthembi-Mahanyele Chairperson of Central Energy Fund Ltd.; Former Deputy Secretary General of the African National Congress (ANC)

\section{Lalit Mansingh}

Former Foreign Secretary of India, Ambassador to the U.S. and High Commissioner to the UK

\section{Thomas R Pickering}

Former U.S. Undersecretary of State and Ambassador to the UN, Russia, India, Israel, Jordan, EI Salvador and Nigeria

\section{Karim Raslan}

Founder \& CEO of the KRA Group

\section{Olympia Snowe}

Former U.S. Senator and member of the House of Representatives

\section{George Soros}

Founder, Open Society Foundations and Chair, Soros Fund Management

\section{Javier Solana}

President, ESADE Center for Global Economy and Geopolitics; Distinguished Fellow, The Brookings Institution

\section{Pär Stenbäck}

Former Minister of Foreign Affairs and of Education, Finland. Chairman of the European Cultural Parliament

\section{Jonas Gahr Støre}

Leader of Norwegian Labour Party; Former Foreign Minister

\section{Lawrence H. Summers}

Former Director of the U.S. Nationa

Economic Council and Secretary of the U.S. Treasury; President Emeritus of Harvard University

\section{Wang Jisi}

Member, Foreign Policy Advisory Committee of the Chinese Foreign Ministry; Former Dean of School

of International Studies, Peking University

\section{Wu Jianmin}

Executive Vice Chairman, China Institute for Innovation and Development Strategy; Member, Foreign Policy Advisory Committee of the Chinese Foreign Ministry; Former Ambassado of China to the UN (Geneva) and France

Lionel Zinsou

Chairman and CEO, PAI Partners 


\section{PRESIDENT'S COUNCIL}

A distinguished group of individual and corporate donors providing essential support and expertise to Crisis Group.

\section{CORPORATE}

BP

Investec Asset Management

Shearman \& Sterling LLP

Statoil (U.K.) Ltd.

White \& Case LLP

\section{INDIVIDUAL}

Anonymous (5)

Scott Bessent

David Brown \& Erika Franke

Stephen \& Jennifer Dattels

Herman De Bode
Andrew Groves

Frank Holmes

Reynold Levy

Ford Nicholson \& Lisa

Wolverton

Maureen White

\section{INTERNATIONAL ADVISORY COUNCIL}

Individual and corporate supporters who play a key role in Crisis Group's efforts to prevent deadly conflict.

CORPORATE

APCO Worldwide Inc.

Atlas Copco AB

BG Group plc

Chevron

Equinox Partners

HSBC Holdings plc

Lockwood Financial Ltd

MasterCard

Shell

Yapı Merkezi Construction and Industry Inc.

\author{
INDIVIDUAL \\ Anonymous \\ Stanley Bergman \& Edward \\ Bergman \\ Elizabeth Bohart \\ Neil \& Sandra DeFeo Family \\ Foundation \\ Joseph Edelman \\ Neemat Frem \\ Seth \& Jane Ginns \\ Ronald Glickman \\ Rita E. Hauser \\ Geoffrey Hsu
}

\author{
George Kellner \\ Faisel Khan \\ David Levy \\ Leslie Lishon \\ Harriet Mouchly-Weiss \\ Ana Luisa Ponti \& Geoffrey R. \\ Hoguet \\ Kerry Propper \\ Michael L. Riordan \\ Nina K. Solarz \\ Horst Sporer \\ VIVA Trust
}

\begin{tabular}{|c|c|c|}
\hline \multicolumn{3}{|l|}{ SENIOR ADVISERS } \\
\hline \multicolumn{3}{|c|}{$\begin{array}{l}\text { Former Board Members who maintain an association with Crisis Group, and whose advice and support are calle } \\
\text { on (to the extent consistent with any other office they may be holding at the time). }\end{array}$} \\
\hline Martti Ahtisaari & Zbigniew Brzezinski & Swanee Hunt \\
\hline Chairman Emeritus & Kim Campbell & James V. Kimsey \\
\hline George Mitchell & Jorge Castañeda & Aleksander Kwasniewski \\
\hline Chairman Emeritus & Naresh Chandra & Todung Mulya Lubis \\
\hline Gareth Evans & Eugene Chien & Allan J. MacEachen \\
\hline \multirow[t]{2}{*}{ President Emeritus } & Joaquim Alberto Chissano & Graça Machel \\
\hline & Victor Chu & Jessica T. Mathews \\
\hline Kenneth Adelman & Mong Joon Chung & Barbara McDougall \\
\hline Adnan Abu-Odeh & Pat Cox & Matthew McHugh \\
\hline HRH Prince Turki al-Faisal & Gianfranco Dell'Alba & Miklós Németh \\
\hline Óscar Arias & Jacques Delors & Christine Ockrent \\
\hline Ersin Arıoğlu & Alain Destexhe & Timothy Ong \\
\hline Richard Armitage & Mou-Shih Ding & Olara Otunnu \\
\hline Diego Arria & Uffe Ellemann-Jensen & Lord (Christopher) Patten \\
\hline Zainab Bangura & Gernot Erler & Shimon Peres \\
\hline Shlomo Ben-Ami & Marika Fahlén & Victor Pinchuk \\
\hline Christoph Bertram & Stanley Fischer & Surin Pitsuwan \\
\hline Alan Blinken & Malcolm Fraser & Cyril Ramaphosa \\
\hline Lakhdar Brahimi & Carla Hills & Fidel V. Ramos \\
\hline
\end{tabular}

